\title{
'WHATEVER IS, IS RIGHT'? ECONOMIC INSTITUTIONS IN PRE-INDUSTRIAL EUROPE (TAWNEY LECTURE 2006)
}

\author{
SHEILAGH OGILVIE
}

\author{
CESIFO WORKING PAPER NO. 2066 \\ CATEGORY 10: EMPIRICAL AND THEORETICAL METHODS \\ August 2007
}
An electronic version of the paper may be downloaded
- from the SSRN website: Www.SSRN.com
- from the RePEc website: Www.RePEc.org
- from the CESifo website: www.CESifo-group.org/wp




\title{
'WHATEVER IS, IS RIGHT'? ECONOMIC INSTITUTIONS IN PRE-INDUSTRIAL EUROPE (TAWNEY LECTURE 2006)
}

\begin{abstract}
Institutions - the structures of rules and norms governing economic transactions - are widely assigned a central role in economic development. Yet economic history is still dominated by the belief that institutions arise and survive because they are economically efficient. This paper shows that alternative explanations of institutions - particularly those incorporating distributional effects - are consistent with economic theory and supported by empirical findings. Distributional conflicts provide a better explanation than efficiency for the core economic institutions of pre-industrial Europe - serfdom, the community, the craft guild, and the merchant guild. The paper concludes by proposing four desiderata for any future economic theory of institutions.
\end{abstract}

JEL Code: N01, N43, O17, O43, P48.

\author{
Sheilagh Ogilvie \\ Faculty of Economics \\ University of Cambridge \\ Austin Robinson Building \\ Sidgwick Avenue \\ Cambridge CB3 9DD \\ United Kingdom \\ sco2@econ.cam.ac.uk
}

This paper is the text of the Tawney Lecture, delivered on 3 April 2006 at the Economic History Society Annual Conference, University of Reading. I would like to thank Michael Bordo, André Carus, Partha Dasgupta, Tracy Dennison, Jeremy Edwards, Bob Evans, Chris Meissner, Avner Offer, Douglas Puffert, Paul Seabright, and Hillay Zmora for many stimulating suggestions; and Nick Crafts for making me think of writing this to begin with. 


\section{'Whatever Is, Is Right'? Economic Institutions in Pre-Industrial Europe}

\section{(Tawney Lecture 2006)}

Economic history used to be so simple. Economics focused on the material world - the production, consumption and exchange of tangible goods and services by people maximizing their well-being, defined according to stable preferences, constrained by resources and technology. Economic history followed suit - adjusting for different resource endowments and technologies, but still concentrating on the material and the physical. Economic life was mainly affected by nature - topography, climate, geology, ecology - and the technology available to manipulate it. So farming patterns arose from soil and climate, given known tools and techniques. Proto-industries followed raw materials, trade routes, and infertile locations where farming was unproductive. Trade arose from factor endowments, technological differences, and transportation. Even something as apparently 'social' as the sexual division of labour derived from human physiology: females 'naturally' specialized in light, unskilled, domestic work that could be combined with childbearing, needed no training, and suited women's bodily weakness.

Anything that could not be explained by nature and technology was ascribed to differences in people's preferences, which were stable and exogenous - something economics did not have much to say about. Analyzing collective or individual preferences was a matter for sociology, psychology, anthropology, or history. Even Gary Becker, legendary for using economics to think about 'non-economic' spheres such marriage, fertility, religion, altruism, and crime, declared that there was no accounting for tastes: 'De gustibus non est disputandum'. ${ }^{1}$ Even when he later sought to make preferences endogenous, Becker decided they changed so slowly as to be stable for most analyses. ${ }^{2}$ Economic historians, too, left historical preferences up to cultural, intellectual and social historians - but often doubted the methods used and steered clear of the whole issue.

Nor were institutions - the structure of humanly devised rules and practices constraining economic decisions - viewed as a matter for economics or economic history. Insofar as economists considered institutions at all, they left them to other disciplines. It was dirty work, someone had to do it, but preferably someone else - jurists, perhaps, or political scientists, or sociologists, or anthropologists. Economic historians relied on legal or political historians to tell them the institutional rules of past economies. Institutions were exogenous - we could take them as given.

The physical and geographical view of economies still has charismatic adherents. In Guns, Germs, and Steel, Jared Diamond has enchanted legions of readers by explaining the last nine thousand years of economic development through geographical characteristics. ${ }^{3}$ Kenneth Pomeranz accounts for the divergent performance of Europe and China since 1750 through coal deposits, disease, ecology, and location relative to exploitable 'peripheries'. ${ }^{4}$ Jeffrey Sachs argues that tardy growth in modern LDCs derives from their location in tropical zones

\footnotetext{
${ }^{1}$ Becker, Economic Approach, esp. p. 14; Stigler and Becker, 'De gustibus'.

${ }^{2}$ Becker, Accounting for Tastes, sought to extend the reach of economics to preference formation, but acknowledged that 'Because of the difficulty of changing culture and its low depreciation rate, culture is largely a "given" to individuals throughout their lifetimes' (p. 16).

${ }^{3}$ Diamond, Guns, Germs, and Steel, e.g. p. 358.

${ }^{4}$ Pomeranz, The Great Divergence, esp. p. 66.
} 
where agricultural techniques are inherently less productive and the disease burden naturally higher. $^{5}$

But recently we have begun to realise there must be more to it. Often economies with similar resources and technologies develop quite differently. ${ }^{6}$ The constraints on economic activity may not just be natural and technical, but also social and political. This has triggered an explosion of interest in what one might call the 'human' side of economic history, especially institutions - 'the rules of the game in a society or, more formally, ... the humanly devised constraints that shape human interaction'?

This new enthusiasm for delving into the 'humanly devised constraints' on economic life is wholly welcome. Exploring institutions has revivified longstanding debates - on protoindustrialization, the commercial revolution, technological innovation, agricultural development, and even the demographic transition and women's work. But as with any new craze, there's also the risk of chasing blindly down a cul-de-sac. The dead end I find most worrying is the tendency to explain institutions as an efficient and beneficial response to the needs of the economy - the view that 'whatever is, is right'. I would like to see institutions transformed from a fashion accessory into an indispensable instrument in the toolkit of every economic historian. To do that, I think it is worth standing back from our first, fine careless rapture, and thinking about how best to incorporate institutions into our long-term research programme. That is what I want to do here.

\section{Efficient Institutions and Economic History}

Once we admitted institutions affected the economy, we needed to know what caused institutions. So economists started trying to bring institutions inside the tent - to make them endogenous to economic analysis. The first approach to this challenge, and still by far the most popular, is to assume that an institution exists to address economic needs in a society. It is a solution to some problem that is preventing people from achieving higher production and consumption. All we have to do is identify the problem, and we'll understand why that institution exists. Any society, this view holds, will get the institutions that are the most efficient in addressing its economic requirements. When these requirements change, institutions will also change.

Like everyone, I would like it to be true that when I saw an institution I could be sure it was an efficient solution to an economic problem. As an economist, I would like it to be true because it explains institutions internally to economics, and because efficiency models are comparatively simple to build. As a human being, I would like it to be true because I could stop worrying about dysfunctional institutions and the misery and inequality they engender. So I'm very sorry to have come to the conclusion that viewing institutions as good solutions to economic problems is too optimistic.

It may seem odd to worry about excessive optimism in a discipline whose grim outlook makes people call it 'the dismal science'. This epithet has proved very tenacious ever since Thomas Carlyle coined it in 1849, and might lead one to celebrate any tendency for economists to adopt a sunnier view of the human condition. But the origins of Carlyle's

\footnotetext{
${ }^{5}$ Sachs, 'Tropical Underdevelopment', e.g. p. 2.

${ }^{6}$ See the the evidence discussed in Hall and Jones, 'Why Do Some'; Rodrik, Subramanian, and Trebbi, 'Institutions'; Acemoglu, Johnson, and Robinson, 'Institutions as the Fundamental Cause'.

${ }^{7}$ North, Institutions, p. 3.
} 
famous indictment should make us pause a little before condemning economics for being 'dismal'. The phrase does not originate - as the urban myth would have it - in Carlyle's reaction to Malthus's views on population. It is true that Carlyle did not like Malthus, objecting to his materialism even more than his pessimism; but at no point did he associate Malthus with 'the dismal science'. Rather, Carlyle invented the term in a pamphlet entitled Occasional Discourse on the Nigger Question, addressing the plight of West Indian planters facing labour shortages after slavery was abolished. Economists in the 1840s explained this through supply and demand: planters were not offering wages high enough to attract workers at prevailing conditions. Carlyle objected not just to this specific diagnosis but to the whole amoral economic approach. For one thing, economics ignored the virtues of 'human governance', by which Carlyle meant stable, long-term relationships of reciprocal command and obedience between superior and inferior groups: 'the Social Science ... which finds the secret of this Universe in supply and demand and reduces the duty of human governors to that of letting men alone ... is a dreary, desolate, and indeed quite abject and distressing one; what we might call ... the dismal science'. ${ }^{8}$ Carlyle's second objection was that economics ignored the inferior beliefs and values held by some cultures, whose members should therefore be guided by cultures with superior mental models: 'Negroes... were born ... to be servants of those that are born wiser than you ... the Whites'. ${ }^{9}$ Third, Carlyle was outraged by economists' morally neutral assumption that 'that Negro and White are unrelated, loose from one another, on a footing of perfect equality, and subject to no law but that of supply and demand according to the Dismal Science' ${ }^{10}$ Finally, Carlyle found it iniquitous that the spiritually sterile laws of supply and demand should supplant the morally infused and organically rooted practices of traditional institutions, answering his own question 'What, then, is practicably to be done?' by advocating a return to traditional norms of life-long servitude 'after the manner of the old European serfs'. ${ }^{11}$ This would not only compel black workers to enjoy the steady work, reciprocal social bonds, and stable guidance which they were not 'wise' enough to choose for themselves, but would also generate 'West Indian fruitfulness', benefiting the entire economy. ${ }^{12}$ Carlyle apostrophized economics as 'dismal', therefore, not because it made depressing predictions but because it was desolate of moral and spiritual content - specifically, because it failed to share his normative views about how society should be organized. ${ }^{13}$

Viewed in this light, being 'dismal' does not appear to be altogether a bad thing - at least, insofar as it refers to attempting neutral explanations rather than moral assessments, analysing all agents 'on a footing of perfect equality', and not assuming that some cultures have better mental models than others or are 'wiser' about people's best interests than they are themselves. Nor do the laws of supply and demand seem altogether depressing in comparison to the laws of traditional institutions - whether West Indian slavery or European serfdom. I would even go so far as to argue that it is when economists are not dismal enough - i.e. when we start claiming that traditional institutions such as serfdom or slavery are efficient - that we

\footnotetext{
${ }^{8}$ Carlyle, Collected Works, Vol. 11, p. 177.

${ }^{9}$ Ibid., p. 205.

${ }^{10}$ Ibid., p. 207.

${ }^{11}$ Ibid., p. 207.

${ }^{12}$ Ibid., p. 207.

${ }^{13}$ As can be seen in Chartism (1839) and Past and Present (1843), Carlyle held highly idealized views of the 'feudalist' societies of the European past, believing that they were morally and economically admirable because they assigned clear social roles to all, and ensured that everyone enjoyed the spiritual benefits of hard and stable work. Carlyle contrasted this with the Hobbesian competition and pauperization which he argued Britain had brought upon itself by pursuing the 'cash nexus' of capitalist industrialization.
} 
risk making fools of ourselves. Economic historians' attitude to traditional institutions, I believe, has tended to err in the direction of excessive optimism. In particular, we have tended to adopt the view that if a particular economic institution has persisted stably for a long time, it must have been efficient - a modern version of Pope's sentiment in his 1732 Essay on Man, that 'whatever is, is right'. ${ }^{14}$

Serfdom was the first pre-industrial European institution to be interpreted using this 'efficiency' framework. In 1971, Douglass North and Robert Thomas proposed their model of the 'Rise of the Western World', according to which serfdom was 'an efficient solution to the existing problems' in medieval economies - a voluntary contract between peasants who provided labour services to lords in exchange for 'the public good of protection and justice'. This contract was efficient given the existing ratio between labour and land; when that ratio changed, serfdom stopped being efficient and soon disappeared. ${ }^{15}$ Some years later Stefano Fenoaltea pointed out serious problems with the North and Thomas model, but concurred that one must make 'the reasonable presumption of economic efficiency'. ${ }^{16}$ Serfdom, Fenoaltea argued, was indeed efficient - not because it minimized transaction costs in providing public goods, but because it constituted 'a means to increase output by imposing the use of a superior technique' and to ensure efficient labour monitoring through 'the stabilization of social roles and hierarchy'. ${ }^{17}$ These original scholars subsequently tacitly abandoned their view that serfdom was efficient, and in the 1980s Douglass North himself shifted over decisively to 'cultural' approaches to institutions (which we will look at shortly). ${ }^{18}$ But the efficiency approach lives on in current revisionist views of the 'second serfdom' in early modern eastern Europe, which regard resurgent manorialism as allocating labour and capital more efficiently than free peasantries because highly informed, profit-maximizing landlords could coordinate investment and innovation optimally. ${ }^{19}$

The other great agrarian institution of pre-modern Europe, the village commune, was also soon reinterpreted as economically efficient, and continues to attract new efficiency models to this day. In 1976 (and again in 1991), Donald McCloskey argued that the medieval village particularly its open field system - was an efficient institution for diversifying risks in the absence of markets for insurance, given peasant risk-aversion. ${ }^{20}$ In 1993 Robert Townsend deployed a full battery of economic analyses on McCloskey's data in a general equilibrium framework and concluded that most institutional features of medieval communes were efficient. ${ }^{21}$ More recent efficiency theorists have disputed the specific arguments of McCloskey and Townsend, while retaining their view that village communes were efficient. Thus, for instance, Gary Richardson has recently claimed that village communes offered 'effective and efficient solutions to the problems facing medieval peasants', specifically helping them manage risk by harnessing norms of reciprocity within the village, ${ }^{22}$ while Steven Nafziger has argued that post-Emancipation Russian communes solved factor market imperfections, thereby providing 'efficient ways to distribute resources'.

\footnotetext{
${ }^{14}$ Pope, 'Essay on Man', Epistle 1, line 294.

${ }^{15}$ North and Thomas, 'An Economic Theory'; North and Thomas, 'The Rise and Fall'; North and Thomas, The Rise of the Western World, here p. 21.

${ }^{16}$ Fenoaltea, 'Authority', p. 713. See also Fenoaltea, 'The Rise'.

${ }^{17}$ Fenoaltea, 'Authority', p. 695.

${ }^{18}$ See North, Structure, e.g. pp. 45-58, 204-5.

${ }^{19}$ For a representative example, see Hagen, Ordinary Prussians, 280-333, 646-654.

${ }^{20}$ McCloskey, 'English Open Fields'; McCloskey, 'The Prudent Peasant'.

${ }^{21}$ Townsend, The Medieval Village Economy.

${ }^{22}$ Richardson, 'The Prudent Village', p. 409.

${ }^{23}$ Nafziger, 'Land Redistributions'.
} 
Craft guilds have also been given an efficiency makeover. Charles Hickson and Earl Thomson offered an 'efficiency-based theory of the social function of entry-restricting guilds' as costminimizing institutions for protecting members from exploitation, collecting capital taxes, and ensuring military protection. ${ }^{24}$ Bo Gustafsson argued that guilds efficiently solved information asymmetries between producers and consumers about product quality. ${ }^{25}$ Reinhard Reith claimed that guilds were an efficient mechanism for technological transfer because they compelled journeymen to travel. ${ }^{26}$ Karl Gunnar Persson argued that guilds constituted a beneficial mechanism whereby 'collusion was institutionalized into co-operation based on a balance of rights and obligations', transaction costs were reduced through regulation of prices and qualities, entitlement crises were mitigated by rationing, and implicit insurance was provided by limiting competition. ${ }^{27}$ Ulrich Pfister argued that craft guilds efficiently solved credit market imperfections and ensured quality control where proto-industries were spatially dispersed. ${ }^{28}$ S. R. Epstein pointed out many weaknesses in these other theories, but claimed that craft guilds 'prospered for more than half a millennium' because they were the costminimizing institution 'to allocate skilled labour efficiently' and 'provide an ideal market structure for innovation' ${ }^{29}$ Recently Jan Luiten van Zanden has drawn broad implications from 'the efficiency of the guilds' for comparisons between Europe and China. ${ }^{30}$

Commercial institutions since the tenth century have also been characterized as efficient. Thus Avner Greif, Paul Milgrom and Barry Weingast argued that merchant guilds, by threatening collective boycotts of rulers who failed to provide commercial security, sustained 'the efficient level of trade' from the twelfth to the fifteenth century. ${ }^{31}$ Separately, Greif also concluded that merchant guilds 'enhanced efficiency by supporting inter-community impersonal exchange' through what he termed the 'community responsibility system'. This was a system of inter-guild reprisals, whereby anyone cheated by a long-distance merchant could legally attack that merchant's entire guild, creating an incentive for guilds to punish members who cheated on contracts. ${ }^{32}$ Oliver Volckart and Antje Mangels dismissed these 'younger' merchant guilds of the twelfth to fifteenth centuries as inefficient cartels, but argued that the 'elder' merchant guilds of the tenth and eleventh centuries were efficient providers of security and contract enforcement as 'club goods' ${ }^{33}$ Ann Carlos and Stephen Nicholas focussed on the monopolistic chartered trading companies of the seventeenth and eighteenth centuries, claiming that they were the most efficient institutions for solving information asymmetries and principal-agent problems in early modern long-distance trade. ${ }^{34}$

A broad miscellany of other pre-modern institutions have also been subjected to the efficiency approach. Thus the Mesta, a guild-like association of shepherds and sheep-owners, long vilified (even by many efficiency theorists) for blocking agricultural improvements in pre-

\footnotetext{
${ }^{24}$ Hickson and Thompson, 'A New Theory', p. 136; on efficiency, see also p. 132.

${ }^{25}$ Gustafsson, 'The Rise and Economic Behaviour'.

${ }^{26}$ Reith, 'Arbeitsmigration'.

${ }^{27}$ Persson, Pre-industrial Economic Growth, pp. 50-4.

${ }^{28}$ Pfister, 'Craft Guilds'.

${ }^{29}$ Epstein, 'Craft Guilds', pp. 684, 692, 704.

${ }^{30}$ Van Zanden, 'Common Workmen', p. 9.

${ }^{31}$ Greif, Milgrom, and Weingast, 'Coordination', esp. pp. 748, 749-50 (on efficiency), 772 (on the merchant guild as 'a nexus of contracts').

${ }^{32}$ Greif, Institutions, p. 338.

${ }^{33}$ Volckart and Mangels, 'Are the Roots', pp. 437-9, 442.

${ }^{34}$ Carlos and Nicholas, 'Giants'; Carlos and Nicholas, 'Agency Problems'
} 
modern Spain, ${ }^{35}$ has now been reinterpreted as an efficient solution to the high cost of building fences to define property rights ${ }^{36}$ and to the problem of 'hold-up' threats by towns denying herds access to common resources. ${ }^{37}$ The noble feud, traditionally condemned as a violent manifestation of aristocratic competition, has been portrayed as enhancing economic efficiency by turning 'the one-shot Prisoner's Dilemmas posed by non-simultaneous transactions between strangers into iterated games where the cheated party had the chance to punish the defector', thereby securing property rights and contract enforcement in impersonal, long-distance trade. ${ }^{38}$ Medieval trade fairs, usually seen as a rent-maximizing assertion of urban or princely privilege, have been reinterpreted as demonstrating, by their sheer longevity, that they were efficient in location and organization. ${ }^{39}$ Even vigilante justice and lynching have been rehabilitated - under the less rebarbative rubric of 'informal legal systems' - as efficient solutions to inadequate contract enforcement in pre-modern societies. ${ }^{40}$

So by now economic historians have reinterpreted pretty well every pre-modern institution in terms of efficiency - as beneficial solutions to one or more obstacles to possible transactions. When conditions changed so these institutions were no longer efficient, they were replaced by new institutions which were once again efficient under the new conditions.

In many ways, this analysis is reassuring. For one thing, it brings institutions in from the cold, making them endogenous to economics rather than leaving them out there as naggingly exogenous parameters, subject to the incalculable whims of other disciplines. For another, it deals with the worrying issue of why apparently inefficient institutions could persist for centuries, instead of being competed out of existence. The new answer is simple: traditional institutions were not inefficient after all. Perhaps most important of all, efficiency theories show we are not really 'dismal': now, finally, economists are respecting the virtues of longterm relationships, reciprocity, cultural beliefs, and traditional social arrangements.

\section{Does Economics Imply that Institutions Are Efficient?}

But are we right to be satisfied with these analyses? Here I do not want to rehearse in detail the arguments that have been levelled against these specific efficiency models of pre-modern institutions. The criticisms are numerous and searching, so much so that no individual efficiency model is widely accepted, even among those who believe that efficiency in general explains institutions. Important though such detailed criticisms are, here I want to go beyond them and look at the broader issue of whether economic logic indeed obliges us to believe that any observed institution must be efficient. Does economics truly tell us that 'whatever is, is right'?

If that were so, economics would truly be a dismal science. But in fact, economics does not say this. The rest of this article tries to distinguish what economics does say, and how it can contribute to a better understanding of pre-industrial institutions.

\footnotetext{
${ }^{35}$ North and Thomas, The Rise of the Western World, pp. 85-8, 127-31.

${ }^{36}$ Nugent and Sanchez, 'The Efficiency of the Spanish Mesta', pp. 261-2, 277-81.

${ }^{37}$ Drelichman, 'A Sheep in Wolf's Clothing', pp. 1, 5, 14, 21.

${ }^{38}$ Volckart, 'The Economics of Feuding', esp. pp. 283 (on efficiency), 296.

${ }^{39}$ Epstein, Freedom and Growth.

${ }^{40}$ For surveys of these arguments, see Little and Sheffield, 'Frontiers and Criminal Justice', esp. pp. 796-7, 806-7 ; Hine, 'Vigilantism', esp. pp. 1230-47; Carrigan, 'Lynching', esp. pp. 415-6.
} 


\subsection{The 'Efficiency' Approach to Institutions}

The view that institutions are efficient arises from the idea that people will not voluntarily choose more costly ways of transacting. Transaction costs consist of 'search and information costs, bargaining and decision costs, policing and enforcement costs' ${ }^{41}$ If these costs are too high, potentially profitable activities will not take place. So individuals and societies experiment with institutional arrangements to solve these problems. ${ }^{42}$ They choose those arrangements that most efficiently reduce transaction costs because such institutions 'yield a stream of benefits which makes it profitable to undergo the costs of innovating this new organizational form, ${ }^{43}$

What one might call the 'strong' version of the efficiency approach - most clearly articulated by the economist Armand Alchian - holds that even if people cannot actually identify which institutions are efficient, an evolutionary process of Darwinian selection ensures that only those institutions survive that are efficient. This implacably weeds out less efficient institutions and ensures that better ways of organizing economic life gradually evolve. ${ }^{44}$ The 'weak' version of the efficiency view, by contrast, holds that institutions initially arise because they are efficient, but are then sometimes kept in being by path dependency long after changes in exogenous parameters render them inefficient. ${ }^{45}$

One problem with both 'strong' and 'weak' versions of the efficiency approach is that they never actually define the happy state of 'efficiency' created by their favoured institutions. They do not distinguish between rationality (agents are doing the best they can for themselves as individuals), Pareto-efficiency (where no-one can be made better off without making someone else worse off), and being 'best' or 'right' in a more general sense (e.g. according with acceptable levels of distributional justice). Yet it is basic to modern economics to recognize that what is rational is not necessarily efficient, and what is efficient is not necessarily best or right (for instance, an outcome can be Pareto-efficient but unacceptably unjust). An even more important point is that in the presence of externalities, an institutional arrangement could be efficient for the individuals transacting (i.e. in their best interests), while being inefficient for society as a whole because it affects the welfare of third parties. These distinctions, routine to economic theorists, are almost universally ignored in efficiency models of historical institutions. The most one can deduce from the rather loose terminology used in such models is that they are certainly claiming more than that the selected institution was rational (i.e., better than the alternatives for the parties involved) and efficient for those parties (i.e. not significantly subject to information asymmetries). They certainly define efficiency as applying to the entire society in some way. But whether they are claiming that the institution is efficient for society as a whole (because there are no externalities and no

\footnotetext{
${ }^{41}$ Dahlman, 'The Problem', p. 148.

${ }^{42}$ For exponents of this view, see, for instance, North, Institutions, e.g. p. 6 ('the major role of institutions in a society is to reduce uncertainty'); Williamson, 'Transaction Cost Economics', e.g. p. 37 (institutions are the 'means by which order is accomplished in a relationship in which potential conflict threatens to undo or upset opportunities to realize mutual gains').

${ }^{43}$ North, 'Institutional Change', esp. p. 119.

${ }^{44}$ Alchian, 'Uncertainty'.

45 This argument is often advanced for merchant guilds. Thus Mangels and Volckart, 'Are the Roots', p. 437, 446-7, argue that merchant guilds became inefficient after the twelfth century; Greif, Milgrom and Weingast, Coordination, p. 773, argue they became inefficient after the fifteenth century; and Carlos and Nicholas, 'Giants', argue that the great chartered merchant 'companies' became inefficient only sometime after the eighteenth century.
} 
information asymmetries) or that it was 'best' for everyone (because it is both Pareto-efficient and not unacceptably unjust) is usually left quite vague.

The efficiency approach is further complicated by the fact that some of its adherents disclaim the term altogether. Thus Karl-Gunnar Persson admits that we cannot be certain that craft guilds were efficient 'because we do not have straightforward efficiency results for bargaining outcomes'; instead he describes guilds as 'adequate and even progressive'. ${ }^{46}$ In like manner, S. R. Epstein repudiates 'the view that guilds were "efficient" institutions', preferring instead the formulation that their 'aggregate social benefits outweighed their costs'. ${ }^{47}$ Avner Greif denies subscribing to an efficiency view of institutions in general, but the specific institutions he selects for study - the Maghribi traders' coalition, the European merchant guild, the Genoese podesteria - all turn out to have been 'efficient' for facilitating medieval commerce. ${ }^{48}$ As these examples show, even scholars who formally repudiate the view that institutions are 'efficient' share the belief that observed institutions exist because they overcome certain obstacles to otherwise possible transactions and thereby benefit the entire economy - because, in Daron Acemoglu's definition, they 'maximize economic growth or aggregate economic welfare' ${ }^{49}$ So these studies, as well, can be included as part of the wider penumbra of the efficiency approach to institutions.

The efficiency approach is certainly consistent with economic reasoning. But is it the only explanation of institutions that satisfies this condition? Not at all. There are at least three feasible alternatives. These explain institutions, respectively, in terms of accidental events and personalities, cultural beliefs and values, and conflicts over the distribution of resources. All three are consistent with economic logic, and at least one (the distributional conflicts approach) deals considerably better than the efficiency approach with externalities and information asymmetries.

\subsection{The 'Accidental' Approach to Institutions}

The 'accidental' approach is about as far removed from the efficiency view as one can get. Indeed, it is often the institutional historian's weapon of choice against the institutional economist. It would probably have been the weapon favoured by Thomas Carlyle, who particularly hated economics for explaining society through impersonal laws instead of 'the biography of great men' ${ }^{50}$ But economics, too, can accommodate models in which accidental events and individual actions, magnified by path dependency, enduringly influence economic outcomes.

The 'accidental' approach disputes the idea that institutions are selected - whether intentionally or evolutionarily - by systematic forces at work in society. Instead, institutions result from random influences - or at least unpredictable ones. The process of technological innovation - at least for 'macro-inventions' - is partly stochastic, and new techniques can jolt institutions onto new paths. Institutional changes are often political; politics consists of diplomacy, warfare, government, legislation, justice, and elections; and these in turn are influenced by individual events and personalities. Key players such as rulers, diplomats, judges, legislators, generals, and admirals take actions which are influenced by their

\footnotetext{
${ }^{46}$ Persson, Pre-industrial Economic Growth, pp. 50-4.

${ }^{47}$ Epstein, 'Craft Guilds in the Premodern Economy', para 7.

${ }^{48}$ Greif, Institutions, pp. 58, 61-3, 71, 74, 79-80, 85-88, 93-4, 96, 98-9, 107, 110-14, 120-3, 247-8 .

${ }^{49}$ Acemoglu, 'A Simple Model', p. 516.

${ }^{50}$ Carlyle, On Heroes, p. 39.
} 
characters and emotions, and suffer medical emergencies, die suddenly, fall in love, or fail to beget viable successors. Natural disasters and epidemics destabilize ruling dynasties,

legitimize leaders, or wipe out their competitors. Military and naval expeditions are affected by weather and luck. Colonies get the legal system brought by the first imperialist culture to colonize them, which is influenced by accidents of discovery and war. ${ }^{51}$

One widely held 'accidental' theory of institutions is that contract enforcement and property rights are profoundly determined by 'legal origins', specifically by roots in English common law or French civil law. Thus Djankov et al. argue that 'many developing countries accepted the formalism in adjudication they now have as part of the transplantation of their legal system from their colonizers ... there is no presumption that the transplanted system is efficient' ${ }^{52}$ Institutional differences between common and civil law are in turn ascribed to the historical accident of 'different law and order environments' in twelfth-century England and France. ${ }^{53}$ Another influential example is Nick Crafts' emphasis on the role of the great cotton macro-inventions in explaining why Britain industrialized before France and - amplified over time through path dependency - the subsequent pattern of Britain's economic growth, its factory industrialization and, by implication, its economic institutions. ${ }^{54}$ In his 1995 summary, Crafts makes it clear that an accidental view is perfectly consistent with economic logic: 'I am still prepared to contemplate a role for accident in economic history or, in terminology that I would prefer, to think in terms of economic models which both permit a role for exogenous technological shocks and also allow on occasions for wide ramifications of those shocks'. ${ }^{55}$ The debates raised by the accidental approach are thus not a question of economic logic, but rather of empirical inquiry into the precise size and frequency of random shocks, and the breadth and depth of their subsequent ramifications.

\subsection{The 'Cultural' Approach to Institutions}

The 'cultural' approach to institutions is a second alternative - although it has more common with the efficiency view than appears at first sight. It is based on the assumption that different societies, social strata, ethnic groups, or religions hold different beliefs, values, and 'mental models'. These motivate people to follow different institutional rules. So institutions come into being because they are consistent with the beliefs and values of the people who use them, and are then held in place by those beliefs and values.

Cultural approaches fall into two schools - the exogenous and endogenous. 'Exogenous' cultural approaches view beliefs and values as coming from outside the economic system, determining the shape of institutions, which in turn affect how the economy works.

'Endogenous' approaches, by contrast, view cultural beliefs and values as being determined inside the economic system, simultaneously with institutions - indeed, as we shall see, some proponents of endogenous-culture have gone so far as to describe beliefs and values as identical to institutions.

\footnotetext{
${ }^{51}$ For one version of the 'accidental' approach to institutions, incorporating path dependency, see Hall, 'Aligning Ontology and Methodology', esp. pp. 384-7.

${ }^{52}$ Djankov et al., 'Courts', pp. 510-11.

${ }^{53}$ Glaeser and Shleifer, 'Legal Origins', pp. 1194-1202.

${ }^{54}$ Crafts, 'Industrial Revolution in Britain and France'; Crafts, 'Exogenous or Endogenous Growth'; Crafts, Leybourne and Mills, 'Trends and Cycles'.

${ }^{55}$ Crafts, 'Macroinventions', p. 597.
} 
Perhaps the most famous example of an exogenous cultural approach is Max Weber's theory that the culture of Protestantism endowed its members with a value for diligence and thrift. This in turn is supposed to have motivated them to choose and follow capitalist institutional rules. Catholics and Hindus, Weber tried to show, held different beliefs and values, so they chose different institutions. ${ }^{56}$

Exogenous cultural theories are not restricted to nineteenth-century idealists, however, but can be found in the work of modern economic historians. In the 1980s, for instance, Douglass North progressively disavowed his original efficiency approach, and came to believe that institutions arose and survived because of people's 'subjective models ${ }^{57}$ In recent work he postulates that 'sometimes ... shared beliefs make up part of the institutional structure of a society', although he repudiates the game-theoretic view (described below), according to which 'beliefs are institutions.$^{58}$ In an application of this approach, North and his co-authors ascribe economic failures in Latin America to 'a system of shared beliefs' about political legitimacy and individual rights, which has blocked the institutions that might guarantee property rights and contract enforcement. ${ }^{59}$ In similar vein, Claudio Véliz claims that the economic under-performance of Iberian America relative to British North America originated in the inflexibility and authoritarianism of Spanish culture compared to the adaptability and innovation favoured by Anglo-Saxon culture; these different value systems in turn gave rise to divergent economic institutions. ${ }^{60}$ David Landes argues that the superior performance of European over non-European economies derived from distinctive European beliefs in changing the world through human intervention, and European values for diligence, thrift, tenacity, honesty and tolerance, which were not shared by non-European cultures, and which gave rise to European institutions that were distinctively 'capitalistic': 'if we learn anything from the history of economic development', Landes writes, 'it is that culture makes all the difference. (Here Max Weber was right on.) ${ }^{61}$ Exogenous cultural theories are also applied on the micro-level, with Gary Richardson contending that Catholic beliefs about the afterlife motivated medieval craftsmen to follow the 'efficient' rules of guilds, while the disappearance of these beliefs with the Protestant Reformation caused guilds to decline. This shows, according to Richardson, that that 'non-economic cultural beliefs can influence the structure of economic institutions and efficiency of the economy by changing the structure and equilibrium of the collective action game'. ${ }^{62}$

Perhaps the most influential recent version of the cultural approach has been Robert Putnam's theory of 'social capital', by which he refers to 'those features of social organization, such as trust, norms, and networks, that can improve the efficiency of society by facilitating coordinated actions' ${ }^{63}$ Putnam contends that some societies are characterized by high social capital because of their 'altruistic' or 'civic' cultures: their members believe in trust, hold norms of reciprocity, and value horizontal social networks. These 'civic' cultures in turn encourage institutions that favour economic growth and political accountability. Putnam argues that these cultural beliefs and values, with their associated institutional manifestations

\footnotetext{
${ }^{56}$ Weber, The Protestant Ethic, e.g. pp. 60, 66-9, 104-5.

${ }^{57}$ See North, Structure, e.g. pp. 45-58, 204-5; North, Institutions, pp. 4, 7-8.

${ }^{58}$ North, Wallis, and Weingast, 'A Conceptual Framework', p. 20 with n. 9.

${ }^{59}$ North, Summerhill, and Weingast, 'Order'.

${ }^{60}$ Véliz, The New World of the Gothic Fox.

${ }^{61}$ Landes, The Wealth and Poverty of Nations, p. 516.

${ }^{62}$ Richardson, 'Craft Guilds and Christianity', p. 177.

${ }^{63}$ Putnam, Making Democracy Work, p. 167.
} 
of strong guilds and communes, explain the superior economic performance of Northern compared to Southern Italy since medieval times. ${ }^{64}$

The cultural approach has been taken furthest of all by those who seek to make culture endogenous to economic institutions. According to this view, beliefs and values are simply part of institutions - there is no analytical distinction between formal legal rules, informal social customs, and inward beliefs and values. Thus Masahiko Aoki defines an 'institution' not as a system of rules and customs, but rather as 'a self-sustaining system of shared beliefs about a salient way in which the game is repeatedly played ${ }^{65}$ Avner Greif regards institutions as being "composed of two interrelated elements: cultural beliefs (how individuals expect others to act in various contingencies) and organizations (the endogenous human constructs that alter the rules of the game) ${ }^{66}$ But Greif views beliefs as far more important than rules, describing how his approach 'places motivation to follow rules - and consequently beliefs and norms - at the center of the analysis' and holds that 'motivation provided by beliefs and norms ... is the linchpin of institutions'. ${ }^{67}$

These perspectives, which derive from a certain game-theoretical approach, define institutions as 'endogenous' and 'self-enforcing', and thus seek to make cultural beliefs endogenous to institutions. ${ }^{68}$ But in doing so they equivocate on a fundamental issue. By laying down this definition, they may either be asserting that all institutions are self-enforcing, or they may merely be specifying a particular analytic framework; it is hard to tell which. If they mean the latter, no one could object, and the question becomes one of empirical usefulness: does the analytic framework in question actually account for all the relevant evidence? (I would argue that it does not.) If they mean the former, then a great deal of explanation is required, which is nowhere given. How are we to understand an assertion that all apparently coercive institutions do not 'really' rest on coercion, but on some kind of homeostatic mechanism invisible to the subjects and victims of coercion? But what else could the assertion mean? If it is telling us that something does not exist that we all deal with every day, we are surely justified in asking just what this means.

The motivation for making cultures endogenous to institutions is clear. According to the 'Folk Theorem' of game theory, a series of repeated games has a very large (possibly infinite) number of possible equilibria. By constraining the belief sets of the players, these possibilities are narrowed down considerably. ${ }^{69}$ But analytical convenience for game theorists cannot be our guiding principle in choosing approaches to the study of institutions.

These more extreme attempts to endogenize culture have tended to result in what one might call a 'cultural efficiency' approach - the assumption that a society gets the institutional rules that can efficiently coexist with its cultural beliefs and values, which are in turn held in place by those efficient institutional rules. This view has very serious implications for economic history, as we shall see shortly.

\footnotetext{
${ }^{64}$ Putnam, Making Democracy Work.

${ }^{65}$ Aoki, Toward a Comparative Institutional Analysis, p. 10.

${ }^{66}$ Greif, 'Cultural Beliefs', p. 943; see also the discussion in Greif, Institutions, p. 14.

${ }^{67}$ Greif, Institutions, pp. 39, 45.

${ }^{68}$ Greif, Institutions, pp. 15-23; Greif and Laitin, 'A Theory', esp. pp. 633-5. This is close to, but not identical with, the view of Calvert, 'Rational Actors', p. 82, that institutions are simply 'equilibria in some underlying, unalterable game'.

${ }^{69}$ Greif, Institutions, esp. p. 20.
} 


\subsection{The 'Conflict' Approach to Institutions}

But first we must consider a final economic approach to institutions - the 'conflict' view. This is based on the idea that institutions affect not just the efficiency of an economy but also how its resources are distributed. That is, institutions affect both the size of the total economic pie and who gets how big a slice. Most people in the economy might well want the pie to be as big as possible - the assumption of the efficiency theorists. But people will typically disagree about how to share out the slices. They may also disagree about what kind of pie it should be, since different people place different weights on various measures of well-being - material consumption, leisure, longevity, fertility, environmental amenities, social equality, political freedom, religious observance, and so on. Since institutions affect not only the size of the pie (through influencing efficiency) but also the type of pie it is (through establishing who is entitled to allocate inputs) and the distribution of the slices (through apportioning the output), people typically disagree about which institutions are best. This causes conflict. Some people strive to maintain particular institutions, others merely cooperate, others quietly sabotage them, and still others resist. Individuals struggle over institutions, but so do groups - and some groups form institutions for that very purpose. Which institution (or set of institutions) results from this conflict will be affected not just by its efficiency but by its distributional implications for the most powerful individuals and groups. ${ }^{70}$

Efficiency theorists do sometimes mention that institutions evoke conflict. But they seldom incorporate conflict into their explanations. Instead, conflict remains an incidental by-product of institutions portrayed as primarily existing to enhance efficiency. Thus, for instance, Douglass North often mentions distributional effects of institutions, but explains their rise and evolution through economic efficiency (in his early studies) or 'mental models' (in more recent work). ${ }^{71}$ Avner Greif also sometimes acknowledges that institutions can have distributional effects, but analyzes the specific institutions he selects - the Maghribi traders' coalition, the European merchant guild - in terms of their efficiency in encouraging medieval commerce and their compatibility with prevailing cultural beliefs. ${ }^{72}$ Insofar as he acknowledges rent-seeking, he characterizes it as efficient, on the grounds that 'monopoly rights generated a stream of rents that depended on the support of other members and so served as a bond, allowing members to commit themselves to collective action' ${ }^{73}$ In like manner, S. R. Epstein argues that the rent-seeking by European craft guilds enhanced

\footnotetext{
${ }^{70}$ For two quite different discussions of why distributional conflicts are likely to influence institutional developments strongly, see Acemoglu, Johnson, and Robinson, 'Institutions as the Fundamental Cause', esp. pp. 389-95, 427-8; and Knight, 'Models', esp. pp. 107-10, 117-18.

71 Thus North and Thomas, 'An Economic Theory', p. 7 n. 1, acknowledge that some of the institutions 'designed to realize the gains inherent in economics of scale or to reduce transactions costs will probably also redistribute income within the economy', but assert that 'this effect is a by-product of the primary objective'. On the primacy of efficiency, see North and Thomas, The Rise; on the importance

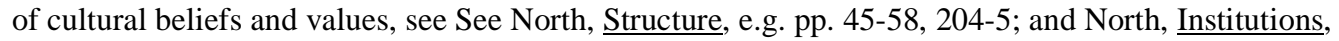
pp. 16, 47-48, 52, 67. In recent work, North focusses on transformation in the distributional effects of institutions as the key to economic development, but still strongly emphasizes 'cognition and the formation of beliefs' in the explanation of institutions; on this see North, Wallis, and Weingast, 'A Conceptual Framework', pp. 8, 20 with n. 9.

${ }^{72}$ Greif, Institutions, pp. 39-45, explicitly disavows the view that institutions are efficient, but then devotes the remainder of his book to game-theoretic models of the institutions that helped medieval societies achieve (for instance) 'efficient' agency relations (ch. 3, pp. 58, 61-2, 71, 80-82, 85, 87-8) and the 'efficient' volume of trade (ch. 4, pp. 93-4, 96-9, 107, 110-15, 117).

${ }^{73}$ Greif, Milgrom, and Weingast, 'Coordination, Commitment, and Enforcement', pp. 749 (quotation), 758.
} 
economic efficiency by enabling early modern states to 'coordinate' the activities of 'decentralized agents' in 'thin markets'. ${ }^{74}$

Yet a 'conflict' approach which incorporates the distributional activities of institutions into its analysis without assuming such activities to be efficient can explain many facts about premodern institutions that 'efficiency' views cannot. A conflict approach would agree, for instance, that there is a good economic reason for the long existence of serfdom. But this was not that it efficiently solved market imperfections in public goods, agricultural innovation, or investment. Rather, serfdom created an economy of privileges that hindered efficient resource allocation in land, labour, capital and output markets. But although serfdom was profoundly ineffective at increasing the size of the economic pie, it was highly effective at distributing large slices to overlords, with fiscal and military side-benefits to rulers and economic privileges for serf elites. ${ }^{75}$

The 'conflict' view would also concur that there is a good economic explanation for why strong peasant communes existed stably for centuries. But this was not because they were efficient for the whole economy. Their regulation of land-markets, migration, technology, settlement, and women's work often hindered the flexible allocation of resources, in ways so innumerable that village micro-studies are still uncovering their true extent and implications. This not only diminished aggregate output but brutally narrowed the consumption and production options of poorer social strata, women, minorities, and migrants. Strong communes persisted not because they efficiently maximized the economic pie, but because they distributed large shares of a limited pie to village elites (large peasants, male household heads), with fiscal, military, and regulatory side-benefits to rulers and overlords. ${ }^{76}$

The 'conflict' approach would also hold that there is a good economic explanation for why craft guilds were widespread in Europe for many centuries. But this was not because they were good for the whole economy. Empirical micro-studies of guilds' actual activities - as opposed to the rhetorical advocacy of their benefits in literature and legislation - show how they underpaid employees, overcharged customers, stifled competition, excluded women and Jews, and blocked innovation. Guilds were widespread not because were good for everyone, but because they benefited well-organized interest groups. They made the pie smaller, but dished out large slices to established male masters, with fiscal and regulatory side-benefits to town governments and princes. ${ }^{77}$

Finally, the 'conflict' view would agree that there is a good economic reason why guild-like merchant associations existed so widely from the twelfth to - in some societies - the nineteenth century. But it was not because they increased aggregate output by guaranteeing commercial security or contract enforcement. Rather, they limited competition and reduced exchange by excluding craftsmen, peasants, women, Jews, foreigners, and the urban proletariat from most profitable branches of commerce. Merchant guilds and associations

\footnotetext{
${ }_{75}^{74}$ Epstein 2007, para. 30.

${ }^{75}$ Brenner, 'Agrarian Class Structure and Economic Development'; Dennison, 'Did Serfdom Matter?'; Melton, 'Enlightened Seigniorialism'; Ogilvie, 'The Economic World'; Dennison and Ogilvie,

'Serfdom and Social Capital'. See also the essays in Peters, Gutsherrschaft; Peters, Gutsherrschaftsgesellschaften; and Kaak and Schattkowsky, Herrschaft.

${ }^{76}$ Dennison and Ogilvie, 'Serfdom and Social Capital'; Melton, 'Enlightened Seigniorialism', here esp. pp. 688-706; Ogilvie, State Corporatism; Robisheaux, Rural Society.

${ }^{77}$ For more detailed exposition of these arguments, see Ogilvie, 'The Use and Abuse of Trust'; Ogilvie, 'Guilds, Efficiency'; Ogilvie, A Bitter Living; Ogilvie, 'Rehabilitating the Guilds'; Ogilvie, 'Can We Rehabilitate the Guilds?'
} 
were so widespread and so tenacious not because they efficiently solved economic problems, making everyone better off, but because they efficiently distributed resources to a powerful urban elite, with side benefits for rulers. ${ }^{78}$ This rent-seeking agreement between political authorities and economic interest-groups was explicitly acknowledged by contemporaries, as in 1736 when the ruler of the German state of Württemberg described the merchant guild that legally monopolized the national worsted proto-industry as 'a substantial national treasure' and extended its commercial privileges at the expense of thousands of impoverished weavers and spinners on the grounds that 'especially on the occasion of the recent French invasion threat and the military taxes that were supposed to be raised, it became apparent that no just opportunity should be lost to hold out a helping hand to [this merchant guild] in all just matters as much as possible' ${ }^{79}$

The conflict view is better than its rivals at explaining why institutions often distribute resources to the powerful rather than maximizing aggregate economic welfare. This is because the conflict view explicitly addresses the problem of institutional externalities. Efficient outcomes are possible only if all affected parties can negotiate their way (without serious problems of asymmetric information) to a binding agreement. But binding agreements pre-suppose an enforcing party with a monopoly of physical violence. And a party with a monopoly of physical violence cannot itself make binding agreements, since by definition there is no other party to enforce them. Therefore a party with a monopoly of physical violence will be under constant temptation to use that capacity to cheat, rob or oppress others (or to support institutional arrangements that coercively distribute resources away from others), thereby inflicting externalities on them. If the monopoly of violence is only local, there will be incentives for arms-race type investments in rivalry against other local monopolies of violence; such arms races are classic examples of externalities leading to suboptimal outcomes. Sometimes rival contenders for local monopolies of violence can negotiate an efficient compromise upheld by threats of retaliation. These outcomes are efficient for the parties negotiating them. But they are capable of inflicting high costs on third parties. Furthermore, they can easily break down as circumstances change, for instance through innovations in military technology. For these reasons, we are likely to observe institutional externalities, whereby a particular institutional arrangement is efficient for the powerful groups that monopolize coercion but inflicts high costs on the rest of society. The conflict view, unlike its rivals, explicitly incorporates such institutional externalities into its analysis.

\subsection{Why Distribution and Efficiency Are Not Separable}

Now, it might be argued that conflicts over distribution could still give rise to efficient institutions. The conflicting parties merely have to agree to let those institutions prevail that will maximize the aggregate pie, and then negotiate on the basis of their coercive power to decide how the slices should be shared out. Indeed, there is an influential school of thought that argues just this - that the efficiency implications and the distributional implications of an institution are separable. According to this view, unequal distribution of coercive power means that the economic institutions we end up with will not be distributionally just, but

\footnotetext{
${ }^{78}$ Dessí and Ogilvie, 'Social Capital and Collusion'; Börner and Ritschl, 'Individual Enforcement'; Jones and Ville, 'Efficient Transactors'.

${ }^{79}$ Quoted in Troeltsch, , Calwer Zeughandlungskompagnie, p. 84 n. 2: 'ein konsiderables Kleinod des Landes'; 'sonderheitlich auch bei der letzten zu befahren gehabten franz. feindl. Invasion und denen zu errichten vorgewesenen Kontributions-Traktaten zu Tage gelegt, dass billig keine Gelegenheit verabsäumt werden solle, derselben in allen billigen Dingen soviel immer möglich, an die Hand zu gehen'.
} 
motives of maximization combined with high probability of bargaining means they will be efficient. ${ }^{80}$ But is this necessarily so? No, for three reasons.

First, people may not know what institutions would most efficiently maximize the aggregate pie, and hence cannot agree about which to support. To use an institution, you need not know that it is efficient, as Alchian pointed out. ${ }^{81}$ But to reach an agreement and engage in bargaining over an institution, you do need to know it is efficient and worth the bargain. Could the overlords and serfs of pre-modern Bohemia, or the privileged merchants and guilded weavers of pre-modern Germany, really know that a certain set of institutional rules would give everyone a bigger pie, over whose distribution they could then bargain?

Second, as already discussed, individuals and groups may disagree about the maximand. Should it be material consumption, leisure, longevity, environmental amenities, social equality, religious observance, or socio-economic stability? Did all the disparate agents of pre-modern Europe truly agree that material output should be maximized, and then bargained over? If fanatical religious Pietists and respectable village householders in early modern Württemberg desired theocratic communities which banned Sabbath work, usury, geographical mobility, gaudy clothes, and female independence, while godless day-labourers and hungry spinners simply wanted rules that let them work, borrow, migrate, consume, and reside in ways that maximized their material well-being, was there room for agreement over the appropriate institutional framework $?^{82}$ Preferences diverge, and the institutions efficient for achieving one set of ends may differ from those efficient for achieving another. If this is so, then the fact that institutions are public goods may preclude any agreement about which should prevail - even before people think about bargaining over the distribution of the output produced using those institutions.

The third obstacle to separating the efficiency of an institution from its distributional impact is that, as already mentioned, holders of coercive power cannot credibly commit to refrain from using it to redistribute resources to their own advantage ex post (i.e. after a certain set of institutions has been established), no matter what distributional agreement they might have made ex ante. ${ }^{83}$ That is, if existing holders of coercive power cede some power so as to bring more efficient institutions into existence, the new holders of power cannot credibly commit to respect the distributional agreement made before the cession of power. For example, if feudal overlords agreed to abolish their legal rights over land, labour, capital and output markets, in return for serfs' continuing to deliver the lion's share of agricultural output to the lords, what was to prevent serfs from walking away with the spoils, once delivered? If guild masters agreed to open up access to their craft and allow competition to bid down the prices of their wares and bid up the costs of their inputs, in exchange for promises that they would continue to receive a stream of payments in lieu of those rents, what was to prevent customers, employees, and new entrants from refusing to deliver these payments once the coercive institutional framework had been abolished? And how could serf overlords, or guild masters, credibly commit to going on making transfers to rulers once they no longer enjoyed the institutional privileges those transfers had purchased?

\footnotetext{
${ }^{80}$ For an example, see Wittman, 'Why Democracies Produce Efficient Results'; for arguments against this view, see Acemoglu, 'Why Not a Political Coase Theorem?'.

${ }^{81}$ Alchian, 'Uncertainty'.

${ }^{82}$ For evidence to the contrary, see Ogilvie, A Bitter Living.

${ }^{83}$ See Acemoglu, 'Why Not a Political Coase Theorem?'.
} 
These three obstacles appear fatal to the programme - on which any efficiency theory must rely - of separating efficiency from distribution. They are inextricably fused. Some have suggested that coercive enforcement of rules must itself be explained endogenously as the outcome of a series of interactions that can be modelled as games. ${ }^{84}$ But any such process is constrained by the same three obstacles just cited. If no credible commitment can be made, then an outcome requiring it cannot be reached by players even in an infinite series of games. The burden is surely on those who entertain such speculations to explain how a coercion-free process could arrive at stable institutional equilibria. Until such an argument, backed by convincing evidence, is forthcoming, historians and economists will certainly continue to regard coercive enforcement and social conflict over its exercise as fundamental parameters in their discussion of institutions.

Since, then, efficiency cannot be separated from distribution by a political analogy to the Coase Theorem, there is no reason to believe that the economic institutions we actually observe will be those that are most efficient - i.e. that maximize the size of the pie. Instead, they will be those that result from rent-seeking struggles and thus reflect the distribution of coercive power in the society. This creates clear possibilities for economic institutions to persist over time, since they affect the distribution of resources. That in turn affects the distribution of coercive power, which in turn further shapes economic institutions, and so on.

\section{$\underline{\text { 3. Desiderata for Any Future Theory of Institutions }}$}

Efficiency is thus not the only explanation for institutions that is consistent with economic reasoning. Institutions can arise through stochastic shocks and persist through path dependency. Institutions can be facilitated or sabotaged by cultural beliefs, values, and 'mental models'. And institutions can arise through conflicts among political groups over the distribution of resources.

I have argued that the conflict approach explains institutional features - particularly institutional externalities - which its rivals cannot. But this is not to reject a possible role for other variables. Increasing the aggregate size of the pie is clearly attractive to most (if not all) social groups, so long as the size of their own slice does not shrink. So if two institutional arrangements have similar distributional implications, I would expect the more efficient to win out. Beliefs and values clearly affect people's motivation to follow institutional rules. So if two institutional arrangements have similar distributional implications, I would expect the one that better accords with the pre-existing beliefs and values of the culture (or its dominant groups) to be adopted and to help replicate those beliefs and values. And every model has an error term, which consists not just of measurement error but of random disturbances.

Especially where coercive power is distributed unequally with much power in the hands of small groups or individuals, stochastic shocks and path dependencies will affect outcomes. In such circumstances, I would expect accidents of personality, technology, weather, discovery and disaster sometimes to change the distribution of coercive power and thereby influence institutions, even though in normal times non-stochastic factors would play a greater role.

A multivariate approach to explaining institutions is thus perfectly consistent with economic reasoning. Such an approach does justice to more economic features of institutions than just their efficiency. It takes account of their distributional implications and their evocation of

${ }^{84}$ Aoki, Toward a Comparative Institutional Analysis; Greif, Institutions. 
conflict. It pays attention to the way beliefs and values motivate compliance with institutional rules. And it recognizes the sensitivity of institutions to random events.

A multivariate approach, I would argue, also offers more promising ways of addressing four additional challenges facing any future economic theory of institutions, which I now propose to discuss. First, institutions do many things, so it is highly misleading to focus selectively on some of those activities and evaluate their efficiency in isolation from all the other things they do. Second, institutions often exclude people from certain activities, leading to black markets and shadow economies. These institutional externalities need to be incorporated into the analysis. Third, institutions do not exist in isolation from a whole interlocking framework of institutions, which our analysis must somehow take into account. Finally, how can we do justice to the interplay between inward beliefs and values on the one hand and institutional rules on the other?

\subsection{Institutions Do Many Things}

A first desideratum for any future theory of institutions is to take into account the fact that any institution does many things. Efficiency approaches generally focus on a single aspect of an institution in isolation. Each model emphasizes a specific activity, and claims that the institution's efficiency in that activity benefited the entire economy. But this ignores a universal feature of institutions - people use them for many purposes. Most of the ways an institution is used will affect efficiency, whether positively or negatively. Moreover, its 'efficient' and 'inefficient' activities are generally not separable; an institution comes as a package. In general, an institution can only do the efficient things it does (if any) by virtue of the other things it does (which may turn out to be inefficient). This means that even if we accept that a certain institution did one thing that increased efficiency, we have to weigh up the effects of all the activities in which it engaged. Only then can we assess whether it was efficient in any general sense.

This is illustrated by efficiency models of serfdom, each of which focuses solely on the specific aspect it sees as efficient. Thus North and Thomas focus on provision of public goods by overlords with a comparative advantage in providing 'protection'. Fenoaltea concentrates on introduction of agricultural innovations by overlords more highly informed than peasants. And scholars of the early modern 'second serfdom' focus on strategic investment by enlightened manorial administrators based on economies of scale in accumulating capital and information. Leaving aside whether serfdom really did bestow these benefits - which has been questioned - we must also ask what else serfdom did. When we do this, a grimmer picture emerges. Serfdom distorted labour markets by entitling overlords to levy coerced labour, compel serfs to work at below-market wages for privileged employers, prevent serfs from migrating freely, and force them to migrate against their will. Serfdom distorted land markets by giving overlords power to mandate land repartitions, prohibit farm divisions, intervene in inheritance, prevent land sales, prohibit mortgages, eject farmers from holdings, and refuse to enforce contracts. Serfdom distorted capital markets by empowering overlords to override private credit agreements, refuse to enforce debt contracts, and destabilize the property rights needed to secure peasant loans. Serfdom debilitated product markets by licensing monopolies and monopsonies, obliging serfs to offer output to overlords at belowmarket prices, and forcing serfs to purchase demesne output at above-market prices. ${ }^{85}$

\footnotetext{
${ }^{85}$ Ogilvie, 'The Economic World', documents these activities in the (relatively mild) Bohemian variant of serfdom. Most variants of serfdom reduced economic efficiency even more brutally; for just one
} 
It might be argued that not all variants of serfdom involved all these distortions. But while we might observe variants of serfdom in which some of these inefficiencies were less farreaching, we never observe a serf system without any manorial intervention in factor or product markets. After all, how could serfdom have created the benefits claimed by the efficiency models - provided protection, introduced innovations, or encouraged strategic investments - without the coercive power that enabled overlords to distort markets? The comparative advantage of overlords in providing protection to serfs was also a comparative advantage in coercively intervening in serf transactions. Insofar as overlords did not have enough coercive power to distort markets, they also lacked the power to provide protection. The supposed efficiency gains from overlords' ability to push through agricultural innovations relied on their power to intervene in labour and land markets, specifically to engross peasant land and levy forced labour services. The efficiency gains from overlords' superiority in accumulating capital and agronomic information derived from the rents they extorted by coercively intervening in factor and product markets. The general lesson is not to jump to conclusions about the economic benefits of an institution without analysing everything it does. If some of its activities produce benefits, do those depend on other activities that impose costs? If they do, then we have to assess both costs and benefits.

The same problem arises with efficiency views of craft guilds. Each model focuses on a single guild activity - controlling quality, transmitting skills, regulating technology - while ignoring others. Leaving aside whether guilds really did generate all these benefits - which even some efficiency theorists question - we must also ask what else guilds did. Most guilds engaged in a wide variety of interlinked economic, social, political, religious and cultural activities. Guilds typically distorted labour markets, forbidding non-members to practise the craft, excluding many applicants from admission, charging discriminatory entrance fees, and legally fixing wages. Guilds distorted markets for physical capital and real estate by prohibiting sales of equipment and workshops to non-members. Guilds distorted product markets by claiming legal monopsonies over raw materials and intermediate products, legal monopolies over output, and the right to fix prices for both inputs and outputs. Guilds engaged in political rentseeking and offered benefits to rulers in return for market privileges. And guilds engaged in cultural display, sociability, religious observance, and other 'motivational' activities. ${ }^{86}$

As in the case of serfdom, it might be argued that craft guilds were highly heterogeneous and not all of them distorted markets in their members' interests. Surely some guilds were flexible and efficient? But the only European craft guilds that lacked the capacity or motivation to intervene in markets to capture rents for their members - Dutch and English guilds after c. 1560 are most often instanced - also lacked the ability and desire to intervene in markets to enhance efficiency. Thus, for instance, guilds could only control quality by enforcing a legal monopoly over certain wares; this necessarily involved intervening in markets for labour (forbidding non-members to practise) and products (preventing non-members from selling output). Likewise, guilds could only ensure training by intervening in labour markets, in particular by excluding non-apprenticed workers and monitoring the background of youths admitted to apprenticeship. Similarly, guilds could only encourage technological knowledge

example, see Dennison, 'Did Serfdom Matter?'; Dennison, 'Economy and Society'. For examples from across eastern-central Europe, see the essays in Peters, Gutsherrschaft; Peters,

Gutsherrschaftsgesellschaften; and Kaak and Schattkowsky, Herrschaft.

${ }^{86}$ Ogilvie, State Corporatism, documents these activities for the weavers' and merchant-dyers' guilds of the Württemberg Black Forest; for analogous examples from other European guild systems, see Ogilvie, 'The Use and Abuse'; Ogilvie, 'Can We Rehabilitate the Guilds?'. 
by securing monopoly rents for members, enforcing apprenticeships to transmit techniques, compelling journeymen to travel, and insisting on spatial clustering. Guilds cannot simultaneously have been unable to enforce inefficient regulations but able to enforce efficient ones. Their very ability to promote efficiency was inseparable from their capacity to cause inefficiency. ${ }^{87}$ In short, we cannot focus on a single institutional activity around which we can build an efficiency model. We have to scrutinize everything an institution did, and only then weigh up its economic impact.

A final illustration is provided by models of merchant guilds that focus solely on those of their activities which are supposed to have made long-distance trade more efficient - guild boycotts against rulers or guild enforcement of collective reprisals. Leaving aside whether merchant guilds really did provide these benefits, we must ask what else they did. Like craft guilds, merchant guilds engaged in a whole range of activities. They successfully lobbied rules for a wide array of legal privileges to trade exclusively in certain wares and locations, exclude non-members from trade, limit membership numbers, and restrict competition among members. They limited entry, making admission contingent on citizenship, ethnicity, religion, gender, residence, wealth, reputation, approval of existing members, and ability to pay entrance fees. Those they excluded, particularly wide strata of craftsmen and foreign traders, engaged in bitter socio-political struggle against the legal privileges of merchant guilds, and formed their own guilds partly to lobby for countervailing privileges from rulers. ${ }^{88}$

Again, it might be argued that merchant guilds varied enormously across Europe. Surely not all merchant guilds necessarily engaged in such efficiency-reducing activities? But this raises two questions. First, why would merchant guilds refrain from rent-seeking activities that benefited their members? Second, were merchant guilds' efficiency-enhancing activities actually separable from their efficiency-reducing ones? Even efficiency theorists tacitly acknowledge that they were not. ${ }^{89}$ Thus, for instance, a merchant guild could credibly threaten a ruler with a boycott only if the guild exercised some market power in that ruler's polity. It could only force its members to comply with such a boycott by securing their loyalty with monopoly rents and penalizing those who sought to free-ride. Likewise, contract enforcement through the 'collective responsibility system' required merchant guilds to be able to regulate entry, motivate members with monopoly rents, and penalize free-riders by excluding them from rents. To coordinate members and negotiate credibly with rulers, a merchant guild had to enjoy the legal right to intervene in markets. Once it had these rights, why should it refrain from using them to redistribute resources in favour of its own members, even if that reduced aggregate welfare for the economy at large?

It is undoubtedly possible to find some respect in which Stalin's collectivization or the Vietnam War were efficient, but historians would rightly be indignant if one left it at that, without acknowledging the costs of these projects. The general lesson is that one and the same institution will typically engage in a wide variety of activities. So it will have a wide variety of effects. Some will enhance economic efficiency, some will harm it, and some will leave it

\footnotetext{
${ }^{87}$ For a detailed analysis of the inseparability of the inefficient from the putatively efficient activities of pre-modern craft guilds, see Ogilvie, 'Guilds, Efficiency, and Social Capital'; Ogilvie, 'The Use and Abuse'; and Ogilvie, 'Can We Rehabilitate the Guilds?'.

${ }^{88}$ For a detailed analysis of these interlinked activities undertaken by merchant guilds all over medieval Europe, see Dessí and Ogilvie, 'Social Capital and Collusion'.

${ }^{89}$ Greif, Institutions, ch. 4 (esp. pp. 100-05) acknowledges that merchant guilds distorted markets and that these distortions were essential to their ability to negotiate with rulers, but then ignores the impact of these distortions on efficiency.
} 
unaffected. We cannot assume in advance that all its activities will be efficient (or inefficient). Any future theory of institutions must take into account that an institution engages in many activities, which all have to be assessed, and may not be separable. Efficiency in one sphere may only be bought at the cost of inefficiency in another and the net effect is not obvious.

\subsection{Formal Institutions and Black Markets}

Any future theory of institutions must also take into account the fact that institutions often exclude people from their benefits - or even from entire spheres of economic activity. The pre-industrial economy in particular was characterized by 'limited-access' institutions that coercively limited economic entry in order to create rents for the powerful, while excluding the vast mass of economic agents. Limiting access not only affects distribution. It also affects efficiency, because it creates incentives for the excluded to violate institutional rules by moving into the informal sector. Informal economic activity is better than none at all, but typically imposes higher costs and risks than if the same agents could do the same things through formal institutions. So a key feature of any formal institution is what kind of informal sector it creates.

Serfdom, for example, prevented serfs from allocating labour, using land, borrowing money, or selling output as they chose. Either they were excluded from these markets altogether, or participation was conditional on following institutional rules so costly that few could afford to comply. This did not mean serfs refrained from transacting in markets altogether. Studies of serfdom 'from below' show serfs selling their own labour, hiring other serfs to work their own plots or do their manorial corvée, and even engaging in migrant labour - ignoring or violating the rules of serfdom. On the Russian serf estate of Voshchazhnikovo in the late eighteenth and early nineteenth century, for instance, T. K. Dennison has demonstrated the existence of a 'semi-formal system of property rights and contract enforcement' which was used by large numbers of local serfs, including many of the poorest. ${ }^{90}$ Parallel or illegal markets in labour, real estate, credit, foodstuffs, raw materials, and craft wares are visible in the shadows surrounding formal manorial regulations in a wide variety of serf economies across pre-modern Europe. ${ }^{91}$

Such findings are sometimes used by efficiency theorists to claim that apparently restrictive manorial regulations had no real effects and hence that serfdom really was efficient. Thus North and Thomas claimed that restrictions on emigration under serfdom could be evaded and hence cannot have impaired efficiency. ${ }^{92}$ Likewise, some recent studies of the 'second serfdom' in eastern Europe claim that manorial controls on serf land transactions could be circumvented and hence serfdom did not significantly constrain efficiency. ${ }^{93}$ But although manorial restrictions on labour and land markets could be avoided, evasion was not costless. ${ }^{94}$ Illegal migration meant abandoning land, non-portable possessions, local inheritance and debt claims, familial ties, and social networks. Illegal labour contracts were unenforceable and

\footnotetext{
${ }^{90}$ Dennison, 'Did Serfdom Matter?', quote from p. 89.

${ }^{91}$ Dennison, 'Did Serfdom Matter?'; Dennison and Ogilvie, 'Serfdom and Social Capital'; Ogilvie, 'The Economic World'; Hagen, Ordinary Prussians; and many of the essays in Peters, Gutsherrschaft; and Peters, Gutsherrschaftsgesellschaften; and Kaak and Schattkowsky, Herrschaft.

${ }^{92}$ North and Thomas, 'The Rise and Fall', pp. 778-81; the view that serf migration restrictions did not impose costs is criticized in Fenoalta, 'Rise and Fall', p. 387.

${ }^{93}$ Hagen, Ordinary Prussians, pp. 137-45, 151, 183, 596-601; 649-54; Pazdérová, 'Gutsherrschaft', pp. 184-5; Štefanová, 'Erbschaftspraxis', ch. 4.

${ }^{94}$ Dennison, 'Did Serfdom Matter?', pp. 83-9; Dennison and Ogilvie, 'Serfdom and Social Capital'; Ogilvie, 'The Economic World'.
} 
often exploitive. Illegal land transactions meant risking manorial and communal sanctions, being unable to enforce contracts legally, and living with insecure property rights. High costs and risks deterred the marginal transaction, reducing exchange and causing deadweight losses. Institutional regulations could indeed be evaded, but evasion was costly to the individual and inefficient for the economy.

Other pre-modern institutions also limited access. Village communities restricted mobility of citizens and outsiders, and regulated occupations, wages, residence, and consumption choices of women, servants, and the lower social strata. Guilds reserved craftwork solely for members and excluded many applicants for admission. As with serfdom, efficiency theories seek to dismiss these limitations on access, claiming that 'barriers to entry were porous, and controls over input markets could be circumvented easily' ${ }^{95}$ Restrictions were certainly evaded, but evasion was not costless. Non-citizens who sought to live in a commune illegally had to avoid official notice, work in the black market, avoid enforcing transactions against legal citizens for fear of being reported, and constantly fear imprisonment or expulsion. Women, Jews, or other outsiders who illegally worked at guilded crafts could not enforce their contracts and risked sanctions if detected. Illegality was so costly that 'informal' workers constantly sought to satisfy entry requirements of formal institutions, which were in turn fixed at high levels precisely to limit entry and generate rents for insiders. Enthusiasts for guilds and communes often dismiss these entry barriers as low. ${ }^{96}$ But they loomed large in the eyes of applicants, as shown by desperate petitions for dispensation. They also affected fundamental life decisions such as marriage and settlement, as shown by examples such as the young German village weaver refused permission to marry in 1785 on the grounds that he "was in no sort of position even to raise the community citizenship and guild mastership admission fees' ${ }^{97}$ Danielle van den Heuvel's recent study of a Dutch shopkeepers' guild liberal enough to admit independent female masters demonstrates that even liberal admissions policies constrained poor applicants, whose admission took off spectacularly in 1753 when the authorities compelled the guild to lower its entry fees. ${ }^{98}$ Institutional barriers to entry thus constituted binding constraints, and black-market work was so unattractive that even poor people were willing to pay to move into the formal sector.

Modern LDCs show the same pattern. Formal institutions limit access to property rights, contract enforcement, credit markets, and work permits. To make a living, excluded groups have to break institutional rules, shifting their economic activities into grey markets - or black ones. Initially, development economists rather romanticized the black market, christening it the 'informal sector' and celebrating its social openness and economic dynamism. Recent assessments are more sobering. The informal sector does offer the excluded - often a majority in society - opportunities better than those they can obtain under formal, limited-access institutions. But these opportunities are still poor. The informal sector does have huge economic dynamism, compared to the costly rigidities imposed by formal institutions. But this dynamism is ultimately choked off by poor contract enforcement and property rights. Risks are high, information is poor, violence and theft are common, time-horizons are short, workers are unprotected, and investments in physical and human capital are limited. ${ }^{99}$ Formal

\footnotetext{
${ }^{95}$ Richardson, 'Guilds, Laws', p. 3.

${ }^{96}$ See, for instance, Stabel, 'Guilds', p. 211.

${ }^{97}$ HSAS A573 Bü 6948, petition of 17 May 1785: 'also auf Keinerley Ort im Stand wären nur die burger- und Meister-Recht costen auf zebringen'.

${ }^{98}$ Van den Heuvel, 'Female Traders in the Dutch Republic', pp. 21-23, esp. Chart 4.

${ }^{99}$ See De Soto, The Other Path; Schneider, 'Shadow Economies'; International Labour Office Mission, 'The Informal Sector'.
} 
institutions that create large informal sectors thus impose inefficiencies on the whole economy. They may also block economic change. As Partha Dasgupta has trenchantly observed, informal institutions may bring benefits in less developed economies, but one should not be "distracted from asking if their continued existence could prevent more productive social arrangements from becoming established, say, in the shape of formal markets. One can even ask whether informal institutions were ever as good as they are frequently made out to have been. ${ }^{100}$

Any theory of institutions must not merely look under the streetlights of the formal sector, therefore, but also venture into the alleys of the shadow economy. Every formal institution creates an informal counterpart, if only because every law creates a crime. But where formal institutions limit access - which most pre-modern ones did - they create much larger informal sectors because they turn entire social groups into potential criminals. Efficiency models usually assume that pre-modern institutions generated benefits for insiders which spilled over as positive externalities for the rest of society - that guilds, or communes, or created the basis for later market economies. But what if it was the reverse? Closed-access institutions, to generate more enticing rents for insiders, had perpetual incentives to push an ever larger share of economic activity into the informal sector, strangling economic growth. An institution must be assessed partly in terms of the shadow it casts.

\subsection{Institutional Frameworks}

A third desideratum for any future theory of institutions is to recognize the importance of selfsustaining institutional frameworks. Efficiency approaches typically focus on one institution at a time: serfdom, the commune, the guild, the property rights system. But institutions do not exist in isolation. Can we really explain any given institution without looking at the wider framework of other institutions surrounding it?

This question came to the fore in the 1990s, when economists were surprised to observe successful western institutions - secure private property rights, impartial contract enforcement - failing to take root in many transition economies. What was wrong? Two stumbling blocks emerged. First, beneficiaries of existing institutions had the incentive and the power to resist innovations that threatened the status quo. Second, existing institutions were held in place by an interconnected framework of other institutions. Typically, the institutions of a society have co-existed for centuries, continually evolving a division of activities, supporting one another in all sorts of ways. These ways may not necessarily be efficient, but they are often selfsustaining. Taking a solitary institution out of its original institutional framework (which may have helped to sustain it), and seeking to transplant it into a quite different framework (which may even resist its encroachment), is not unlikely to fail. ${ }^{101}$

The interdependency of individual institutions within a wider framework has been recognized by some studies of European economic institutions. The European family system, according to Peter Laslett, was interdependent with labour markets for youths and women, credit markets to amass savings, and collective rather than kin-based provision of insurance and pensions; this whole interlinked institutional system, Laslett speculates, contributed to early

${ }^{100}$ Dasgupta, 'Social Capital and Economic Progress', p. 310.

${ }^{101}$ North, Institutions, pp. 7-8, touches in passing on the idea of institutional frameworks to explain the persistence of inefficient institutions, but abandons it to pursue explanations in terms of 'imperfect subjective models'. Institutional and technological 'interrelatedness' have also been used to explain the persistence of inefficient techniques; see David, 'Clio'; and Scott, 'Path Dependence'. 
industrialization and capitalism. ${ }^{102}$ The community-based welfare system in pre-industrial England, according to Peter Solar, was interdependent with labour markets, land markets, credit markets, and the nuclear family system; this distinctive framework, he argues, may have furthered economic growth in the centuries before industrialization. ${ }^{103}$ Cross-country comparisons, according to Daron Acemoglu and Simon Johnson, suggest that favourable 'contracting' institutions (those regulating interactions between private citizens) may be partially interdependent with favourable 'property rights' institutions (those constraining the behaviour of political and economic elites). ${ }^{104}$

If such interdependencies are widespread, then we cannot study one institution in isolation. We have to look at entire institutional frameworks. When we do so, we may find that there are inherent complementarities between certain institutions, and that a whole cluster of institutions may be mutually reinforcing. The historical clusters identified by Laslett, Solar, Acemoglu and Johnson were all efficient. But self-reinforcing institutional frameworks might also be inefficient. In modern LDCs, for instance, retention of existing techniques and institutions despite alternatives that are known to be more productive is ascribed to institutional interlinkages among markets. Any innovation would disequilibrate an entire system of interlinked markets, and so is rejected unless it provides substitutes for everything it threatens to displace. ${ }^{105}$ Whether self-reinforcing institutional frameworks are efficient or not, they are analytically essential to understanding the origins and economic impact of any individual institution.

\subsection{What Do We Do About Culture?}

A final desideratum for any future theory of institutions is to do justice to the interplay between inward beliefs and values on the one hand and institutional rules on the other. As efficiency theories came under fire, economists began to cast about for surrogates. One popular choice was the cultural approach. The Achilles heel of the efficiency theory, this argument goes, was to ignore what went on inside people's heads - beliefs, values, and mental models. Maybe if we brought these into our toolkit, we might construct better models of how institutions work?

So Douglass North progressively abandoned his efficiency theories in the course of the 1980s, espousing the view that institutions evolved not because they were efficient but because they were fostered by the 'mental model' of a particular culture. ${ }^{106}$ Thus efficient economic institutions were generated by good mental models in the western world, and less efficient institutions by different mental models in 'primitive societies', early modern Iberia, or the present-day Third World. ${ }^{107}$ Other economic historians underwent an even more far-reaching reorientation, as we have seen, advocating an 'endogenous-culture' approach which defined an institution as a system of rules and cultural beliefs, in which beliefs were the dominant

\footnotetext{
${ }^{102}$ Laslett, 'The European Family'.

${ }^{103}$ Solar, 'Poor Relief', here esp. p. 16: 'The old poor law ... underpinned the growth of an economically mobile wage labour force; encouraged the consolidation of farms and facilitated the separation of smallholders from the land; provided local incentives for agricultural capital formation and industrial development; and kept population growth under control.'

${ }^{104}$ Acemoglu and Johnson, 'Unbundling Institutions'.

${ }^{105}$ For an excellent discussion of 'interlinked factor markets', see Basu, Analytical Development Economics, ch. 13-14.

${ }^{106}$ See North, Structure, e.g. pp. 45-58, 204-5.

${ }^{107}$ North, Institutions, pp. 9, 34-35
} 
component. ${ }^{108}$ Thus Avner Greif counterposed the 'collectivist' cultural beliefs of the Maghribi traders ('non-Muslims who adopted the values of the Muslim society') with the 'individualistic' culture of the Genoese. ${ }^{109}$ Despite facing the same technology and the same commercial opportunities, the two groups adopted widely differing solutions to the problem of contract enforcement, with the Maghribis choosing institutions that provided collective enforcement while the Genoese chose 'legal, political, and (second-party) economic organizations for enforcement and coordination'. ${ }^{110}$ The only possible explanation for this, according to Greif, is that the Maghribis held collectivist beliefs and the Genoese held individualistic ones. This in turn led to long-term economic decline for the collectivist Maghribis and economic dominance by the Genoese and their individualistic fellow Italians. From this Greif draws conclusions for the present-day less developed world: 'the Maghribis' institutions resemble those of contemporary developing countries, whereas the Genoese institutions resemble the developed West, suggesting that the individualistic system may have been more efficient in the long run'. ${ }^{111}$

In practice, therefore, incorporating beliefs and values into economic analyses of institutions has given rise to what one might call a 'cultural efficiency' approach. This theory assumes that good cultural beliefs combine with good societal rules to form good institutions that favour economic growth. Cultures that hold the 'right' beliefs arrive at the right institutional equilibrium and therefore prosper. By studying the institutional equilibria generated in these fortunate cultures, we will understand the sources of economic well-being. In essence, this reduces the problem of explaining institutions to one that can be addressed through an efficiency model with cultural beliefs and values thrown in as 'motivation'.

Here, finally, the 'dismal science' has advanced a theory - that economic well-being is ultimately a matter of cultural beliefs and values - which Thomas Carlyle, with his view of 'wise' whites and feckless blacks, would have heartily embraced. But does this 'cultural efficiency' theory solve all our problems? Frankly, I do not think that this is an adequate way to incorporate cultural beliefs and values into economics, and I am particularly concerned about the suggestion that institutions should be defined as consisting of systems of beliefs as well as (or instead of) systems of rules.

For one thing, inwardly held beliefs, values, norms, and mental models are extremely difficult to observe. Although beliefs are incorporated into game-theoretic models somewhat differently from norms, they share a key analytical characteristic: by definition, they take place inside people's heads and outside observers can measure them indirectly, at best. What people say they believe or value or find normal does not provide an accurate picture of the beliefs, values, and norms on which they take action. It is precisely this, indeed, that gave rise to the crucial analytical distinction in economics between 'stated' and 'revealed' preferences. Even economists working on modern societies, with inconceivably rich datasets on people's beliefs, preferences, attitudes, political affiliations, religion, ethnicity, language, and nationality, differ fundamentally about whether it is possible to identify an independent role for cultural beliefs and values, because those are so interdependent with other variables among which the institutional rules of the society figure predominantly. ${ }^{12}$ As endogenous-

${ }^{108}$ Greif, Institutions, pp. 39, 45.

${ }^{109}$ On this see esp. Greif, Institutions, ch. 3 and ch. 9 (quotation from p. 279).

${ }^{110}$ Greif, Institutions, p. 300.

111 Greif, Institutions, p. 301.

${ }^{112}$ For diametrically opposed views on this issue in recent literature, see Acemoglu, Johnson, and Robinson, 'Institutions as the Fundamental Cause', pp. 401-02, 424-5, who find no systematic effect of 
culture theorists themselves admit, regarding inward beliefs or preferences as part of institutions gives rise to empirical indeterminacy, since the 'rules' component of institutions is observable and the 'norms' component is unobservable: this means that 'we cannot study institutions inductively based on their observable components'. ${ }^{113}$

Nor do we have any generally accepted explanation for norms and beliefs. 'Cultural efficiency' models either turn a blind eye to this problem, or invoke ad hoc speculations such as Avner Greif's statement (buttressed by ample reference to Freud) that 'norms link transactions between the superego and the ego or id'. ${ }^{114}$

If inward beliefs and values are largely unobservable and unexplained in modern economies, how much more so are they in historical ones? How much do we really learn from an approach whereby we plug something we cannot observe and cannot explain into our model as an assumption, and it influences the institutional equilibrium we obtain on the other end? If we are going to postulate that beliefs are the linchpin of institutions, and that it is they rather than the formal rules that matter, then we should propose this as a hypothesis for testing, rather than accepting it as an assumption on which to build our explanations. If we want to test it, then we need to develop more sophisticated ways to think about beliefs and values, devise rigorous methods to observe and measure them, explore how they affect people's economic choices, and explain how they are formed.

A further problem with 'cultural efficiency' approaches is their arbitrary definition of some cultures as holding beliefs and values that are economically 'good' - Protestant diligence, English individualism, European rationality. The implicit assumption is that all the beliefs and values of such 'good' cultures yield 'good' institutional rules that lead to 'good' economic outcomes. But can we just assume this? Do we not at least have to consider the possibility that any culture is a mixture, with some of its beliefs and values benefiting economic performance and others harming it? At the risk of repeating a cliché, individualism is thought to encourage positive economic outcomes such as flexible resource allocation and swift innovation. But individualistic cultures are also thought to value family and communities bonds less, bringing negative outcomes such as crime, addiction and divorce. If we are going to pursue cultural efficiency models, we need much more rigorous theories - and preferably also empirical findings - about which beliefs and values are economically beneficial, in what ways, and whether they always coexist in the same culture.

Finally, even if there were economies - whether historical or modern - where we could observe inwardly held beliefs and preferences in some meaningful way, and where we could know for sure that these beliefs and values were economically relevant, it is still not clear that regarding beliefs and values as a component of institutions would help us explain differences in economic outcomes. For example, much of the women's history literature argues that restrictions on females in pre-industrial economies were caused by 'patriarchal' beliefs and values. But, as I have discussed elsewhere, 'patriarchal' attitudes were universal in early modern Europe. In practice, however, indicators of female economic autonomy varied

cultural variables; and Guiso, Sapienza, and Zingales, 'Does Culture Affect Economic Outcomes?', who argue that culture plays a major role.

${ }^{113}$ Greif, Institutions, p. 20. See also North, Institutions, p. 43, for the acknowledgement that the 'informal institutional constraints' represented by cultural norms are 'not directly observable'.

${ }^{114}$ Greif, Institutions, p. 48 with n. 19; for incorporation of this Freudian perspective into the wider analysis, see also p. 145. North, Institutions, p. 87, admits that informal institutional constraints change only through cultural change, something 'we do not have any theory to explain'. 
significantly across European economies. Female household headship and labour force participation were significantly lower where guilds, communities and manorial systems provided male elites with institutional powers to enforce 'patriarchal' beliefs in pursuit of rents for themselves. In the Netherlands and England, such institutions were weak or missing, and women's economic position measurably better. The same patriarchal beliefs and values coexisted with different institutional rules and divergent economic outcomes. ${ }^{115}$ Likewise, Acemoglu et al. have pointed out that 'British' cultural beliefs gave rise to very different economic institutions in different colonies. In densely settled societies such as India and the Caribbean, British culture gave rise to highly oppressive economic institutions devoted to extracting resources from the indigenous population. In sparsely populated areas such as the northern United States, Canada, and New Zealand, British culture gave rise to beneficent economic institutions that enforced contracts, protected property rights, and encouraged investment. ${ }^{116}$ The same 'British' beliefs and values coexisted with different institutional rules, giving rise to divergent economic outcomes. Very recent history throws up even more striking examples: Korean culture, for instance, has given rise to different institutional rules and widely divergent economic outcomes in North and South Korea.

Such examples pose two serious problems for cultural approaches to institutions. First, if the same cultural beliefs coexist with different rules, and this gives rise to different economic outcomes, then can beliefs really be the 'linchpin' of economic institutions? Second, is it really analytically helpful to view inwardly held beliefs as being identical to - or inseparable from - externally imposed rules? Either these are analytical categories, or they refer to empirical categories of mental and social objects. If the former, then we must judge the models concerned by their empirical predictions (which, I argue, fail). If the latter, then fusing them prevents us from determining whether there are cases where outcomes are determined by one without the other.

One might ask whether it is truly important to know whether beliefs or rules are driving institutions. Surely one can simply think of them as the 'informal' and 'formal' ends of the same spectrum of humanly devised constraints on behaviour? Does it really matter which part of this spectrum brings about a particular institutional equilibrium? I think it does matter; indeed, I think it has far-reaching implications for understanding how economies can grow and develop. If achieving better economic outcomes just requires better formal rules, then any culture can do it, and it is just a question of figuring out the practical barriers to introducing better rules. This may not be easy, but it is in principle possible. But if achieving better economic outcomes requires changing people's beliefs and values, then this implies one of two deeply worrying policy alternatives. Either we just accept that some cultures will always stay poor. Or we advocate policies to eradicate 'bad' beliefs and values, or transform them (by force, in necessary) into 'good' ones. These are rather hair-raising policy conclusions to derive from an explanatory variable - cultural beliefs and values - which even its enthusiasts admit is unobservable and unexplained.

I would therefore make a modest proposal about how to deal with culture. The study of institutions is, and should remain, an empirical matter. To this end, I suggest that we retain the empirically useful distinction between (observable) rules and (unobservable) beliefs, and that we try to explain as much as possible in terms of observable variables - such as rules and

\footnotetext{
115 Ogilvie, Bitter Living; Ogilvie, 'Women and Labour Markets'; Ogilvie, "“Eine sauere Nahrung”, ${ }^{116}$ Acemoglu, Johnson, and Robinson, 'Institutions as the Fundamental Cause', p. 424-5.
} 
their distributional implications - before resorting to unobservable differences between cultural beliefs.

\section{Can We Explain Economic Institutions?}

So where does this leave us in explaining economic institutions? The entire passage of Alexander Pope's Essay on Man, culminating in the line quoted in my title, is a crescendo of faith in the idea that there is an underlying system behind the apparent disorder of nature. For this reason, these lines are often held to epitomize the Enlightenment belief in science. Certainly, the belief in an ordered universe as laid out in the Essay on Man has proved profoundly attractive to social scientists seeking to account for something so messy as the human condition.

But if you look more closely at these six famous lines, they fall into two quite different halves. The first half indeed exhorts us to engage in rational inquiry:

All Nature is but Art, unknown to thee;

All Chance, Direction, which thou canst not see;

All Discord, Harmony, not understood;

We are implicitly urged to question what is apparently natural, accidental and chaotic, to replace what is unknown, unseen, and not understood with a reasoned understanding of the true order underlying it all.

But in the next three lines Pope subtly shifts his ground. Now we find ourselves being invited to accept things on faith:

All partial Evil, universal Good:

And spite of Pride, in erring Reason's spite,

One truth is clear, 'Whatever is, is right.'

We are urged to reject human reason as a manifestation of pride, and instead simply to believe in the moral rightness of the order that will be uncovered.

The first of these views is indeed consistent with the Enlightenment origins of economics the idea that everything in the world is explicable to human inquiry. These Enlightenment roots have taken us a long way in explaining human action. But believing that things are in principle explicable does not entail believing that they're right. Just as 'rightness'

(functioning for ends that are morally good) is only one possible explanation for 'nature', so 'efficiency' (functioning for ends that benefit everyone) is only one possible explanation for institutions.

Economic approaches to historical institutions have been partially discredited, I believe, by a widespread tendency to confuse the view that 'institutions exist for a reason and we can find out that reason' with the belief that 'institutions exist for a reason and that reason is that they are good'. Empirical studies have provided rich evidence that economic models based on the view that 'whatever is, is right' do not adequately explain the rise, functioning, survival or decline of the pre-industrial institutions to which they have been applied.

Does this mean that economic historians should once again retreat to the golden age in which we concentrated on geographical and technological constraints, and leave messy social phenomena such as institutions up to other disciplines? 
My answer is 'no'. I have argued here that there are alternative approaches to institutions which are fully consistent with economic reasoning. In particular, 'conflict' models offer promising and hitherto hardly explored perspectives for explaining institutions in terms of their distributional implications and the socio-political struggles to which these give rise. Even more work remains to be done on both 'accidental' and 'cultural' models. The conditions under which institutions are affected by stochastic processes and path dependency need to be carefully defined and explored. Cultural models face even more serious challenges. First, they must develop more rigorous approaches to identifying, measuring, and explaining people's beliefs and values. Second, they still too often degenerate into 'cultural efficiency' models implying that the 'right' cultural norms give rise to the 'right' institutional rules which then have the 'right' economic outcomes. We need to determine which beliefs and values (if any) are economically relevant, whether economically 'good' values always co-exist in the same culture, and what are the policy implications of cultural determinism.

Whatever explanatory models we develop will only succeed if they can tackle three further challenges. First, they need to weigh up the different efficiency implications of the multiple activities typical of any institution. Second, they need to examine the extent to which institutions limit access and push economic activity into the informal sector, thereby harming both efficiency and equity. And finally, they need to recognize that institutions are embedded in broader institutional frameworks that themselves require economic analysis.

Although institutions are indeed very messy, that just makes them more interesting, in ways we have hitherto hardly begun to explore. The last eight hundred years of economic history potentially holds important lessons for building institutions today. Economic history does not show that 'whatever is, is right'. But perhaps we can adopt a more modest motto, and one truer to our Enlightenment roots, and declare that 'whatever is, is explicable'. 


\section{$\underline{\text { References }}$}

Acemoglu, Daron, 'A Simple Model of Inefficient Institutions', Scandinavian Journal of Economics, 108, 4 (2006), 515-546.

Acemoglu, Daron, 'Why Not a Political Coase Theorem? Social Conflict, Commitment and Politics', Journal of Comparative Economics, 31 (2003), 620-652.

Acemoglu, Daron, and Johnson, Simon, 'Unbundling Institutions', NBER Working Paper 9934 (2003).

Acemoglu, Daron, Johnson, Simon, and Robinson, James, 'Institutions as the Fundamental Cause of Long-Run Growth', in Philippe Aghion and Steven Durlauf (eds.), Handbook of Economic Growth (Amsterdam / London, 2005), 385-472.

Alchian, Armen A., 'Uncertainty, Evolution, and Economic Theory', Journal of Political Economy, 58 (1950), 211-221.

Aoki, Masahiko, Toward a Comparative Institutional Analysis (Cambridge, MA, 2001).

Basu, Kaushik, Analytical Development Economics: the Less Developed Economy Revisited (1997), ch. 13-14.

Becker, Gary S., The Economic Approach to Human Behavior (Chicago, 1976).

Becker, Gary S., Accounting for Tastes (Cambridge, MA, 1996).

Börner, Lars, and Ritschl, Albrecht, 'Individual Enforcement of Collective Liability in PreModern Europe. Comments on Avner Greif', Journal of Institutional and Theoretical Economics 158 (2002), 205-213.

Brenner, Robert, 'Agrarian Class Structure and Economic Development in Pre-Industrial Europe', Past and Present, 70 (1976), 30-75.

Brenner, Robert, 'Agrarian Class Structure and Economic Development in Pre-Industrial Europe: the AgrarianRoots of European Capitalism', Past and Present, 97 (1982), 213-327.

Carlos, Ann M. and Nicholas, Stephen, “'Giants of an Earlier Capitalism”: the Chartered Trading Companies as an Analogue of the Modern Multinational', Business History Review, 26, 3 (1988), 398-419.

Carlos, Ann M. and Nicholas, Stephen, 'Agency Problems in Early Chartered Companies: the Case of the Hudson's Bay Company', Journal of Economic History, 50, 4 (1990), 853-875.

Calvert, Randall L., 'Rational Actors, Equilibrium, and Social Institutions', in Jack Knight and Itai Sened (eds.), Explaining Social Institutions (Ann Arbor, MI, 1995), 57-94.

Carlyle, Thomas, Collected Works of Thomas Carlyle in 31 Volumes, edited by H. D. Traill (London, 1896-1899).

Carlyle, Thomas, On Heroes, Hero-Worship, and the Heroic in History (London, 1897; first published 1841).

Carrigan, William D. and Webb, Clive, 'The Lynching of Persons of Mexican Origin or Descent in the United States, 1848 to 1928', Journal of Social History, 37, 2 (2003), 411-438.

Crafts, N. F. R., 'Industrial Revolution in Britain and France: Some Thoughts on the Question, "Why Was Britain First?", Economic History Review, 2nd ser. 30 (1977), pp. 429-441.

Crafts, N. F. R., 'Exogenous or Endogenous Growth? The Industrial Revolution Reconsidered', Journal of Economic History, 55, 4 (1995), pp. 745-772.

Crafts, N. F. R., Leybourne, S. J. and Mills, T. C., 'Trends and Cycles in British Industrial Production, 1700-1913', Journal of the Royal Statistical Society Series A (Statistics in Society), 152, 1 (1989), pp. 43-60.

Dahlman, Carl J., 'The Problem of Externality', Journal of Law and Economics, 22 (1979), 141-162.

Dasgupta, Partha, 'Social Capital and Economic Progress: Analytics', in E. Ostrom and T. K. Ahn (eds.), Social Capital: a Reader (Cheltenham, 2003).

David, Paul A., 'Clio and the Economics of QWERTY', American Economic Review, Papers and Proceedings, 75, 2 (1985), 332-337. 
Dennison, T. K., 'Economy and society in rural Russia: the serf estate of Voshchazhnikovo, 1750-1860' (Ph.D. dissertation, University of Cambridge, 2004).

Dennison, T. K., 'Did Serfdom Matter? Russian Rural Society 1750-1860', Historical Research, 79 (2006), 74-89.

Dennison, T. K., and Ogilvie, Sheilagh, 'Serfdom and Social Capital in Bohemia and Russia', Economic History Review 60 (2007), 513-544.

De Soto, Hernando, The Other Path: the Invisible Revolution in the Third World (New York, 1989).

Dessí, Roberta, and Ogilvie, Sheilagh, 'Social Capital and Collusion: The Case of Merchant Guilds (Long Version)', Cambridge Working Papers in Economics No. 417 (March, 2004).

Diamond, Jared, Guns, Germs, and Steel: the Fate of Human Societies (New York, 1997).

Djankov, Simeon, LaPorta, Rafael, Lopez-de-Silanes, Florencio and Shleifer, Andrei, 'Courts', Quarterly Journal of Economics, 118 (2003), 453-517.

Epstein, S. R., 'Craft Guilds, Apprenticeship, and Technological Change in Preindustrial Europe', Journal of Economic History 58 (1998), 684-713.

Epstein, S. R., Freedom and Growth: The Rise of States and Markets in Europe, 1300-1750 (New York, 2000).

Epstein, S. R., 'Craft Guilds in the Premodern Economy: a Discussion', Economic History Review, 61 (2008).

Fenoaltea, Stefano, 'Authority, Efficiency, and Agricultural Organization in Medieval England and Beyond: a Hypothesis', Journal of Economic History, 35:4 (1975), 693718.

Fenoaltea, Stefano, 'The Rise and Fall of a Theoretical Model: the Manorial System', Journal of Economic History, 35:2 (1975), 386-409.

Glaeser, Edward and Shleifer, Andrei, 'Legal Origins', Quarterly Journal of Economics, 2002, 117 (2002), 1193-1230.

Greif, Avner, 'Cultural Beliefs and the Organization of Society: Historical and Theoretical Reflection on Collectivist and Individualist Societies', Journal of Political Economy, 102 (1994), 912-950.

Greif, Avner, 'Institutions and Impersonal Exchange: From Communal to Individual Responsibility', Journal of Institutional and Theoretical Economics, 158 (2000), 168204.

Greif, Avner, Institutions and the Path to the Modern Economy: Lessons from Medieval Trade (Cambridge, 2006).

Greif, Avner, 'Family structure, institutions, and growth: the origins and implications of western corporations', American Economic Review Papers and Proceedings, 96 (2006), 308-312.

Greif, Avner and Laitin, David, 'A Theory of Endogenous Institutional Change', American Political Science Review, 98, 4 (2004), pp. 633-652.

Greif, Avner, Milgrom, Paul, and Weingast, Barry R., 'Coordination, Commitment, and Enforcement: the Case of the Merchant Guild', Journal of Political Economy, 102 (1994), 745-76.

Guiso, Luigi, Sapienza, Paola and Zingales, Luigi, 'Does Culture Affect Economic Outcomes?', Journal of Economic Perspectives, 20, 2 (2006), pp. 23-48.

Gustafsson, Bo, 'The Rise and Economic Behaviour of Medieval Craft Guilds', Scandinavian Economic History Review, 35 (1987), 1-40.

Hagen, William W., Ordinary Prussians: Brandenburg Junkers and Villagers, 1500-1840 (Cambridge, 2002).

Hall, Peter A., 'Aligning Ontology and Methodology in Comparative Research', in James Mahoney and Dietrich Rueschemeyer (eds.), Comparative Historical Analysis: New Approaches and Methods (Cambridge, 2003), pp. 373-406.

Hall, Robert E., and Jones, Charles I., 'Why Do Some Countries Produce So Much More Output Per Worker Than Others?', Quarterly Journal of Economics, 114 (1999), 83116. 
Hickson, Charles R., and Thompson, Earl A., 'A New Theory of Guilds and European Economic Development', Explorations in Economic History 28 (1991), 127-168.

Hine, Kelly D., 'Vigilantism Revisited: an Economic Analysis of the Law of Extra-Judicial Self-Help or Why Can't Dick Shoot Henry for Stealing Jane's Truck', American University Law Review, 47 (1998), 1221-1255.

International Labour Office Mission, 'The Informal Sector', in G. M. Meier (ed.), Leading Issues in Economic Development (Oxford, 1989), 147-151.

Jones, S. R. H. and Ville, S. P., 'Efficient Transactors or Rent-Seeking Monopolist? The Rationale for Early Chartered Trading Companies', Journal of Economic History, 56, 4 (1996), 898-916.

Kaak, Heinrich and Schattkowsky, Martina (eds.), Herrschaft. Machtentfaltung über adligen und fürstlichen Grundbesitz in der Frühen Neuzeit (Cologne / Weimar / Vienna, 2003).

Knight, Jack, 'Models, Interpretations, and Theories: Constructing Explanations of Institutional Emergence and Change', in Jack Knight and Itai Sened (eds.), Explaining Social Institutions (Ann Arbor, MI, 1995).

Landes, David S., The Wealth and Poverty of Nations: Why Some Are So Rich and Some So Poor (New York, 1998).

Laslett, Peter, 'The European Family and Early Industrialization', in Jean Baechler, John A. Hall and Michael Mann (eds.), Europe and the Rise of Capitalism (Oxford, 1988), 234-242.

Little, Craig B. and Sheffield, Christopher P., 'Frontiers and Criminal Justice: English Private Prosecution Societies and American Vigilantism in the Eighteenth and Nineteenth Centuries', American Sociological Review, 48, 6 (1983),796-808.

McCloskey, Donald, 'English Open Fields as Behavior Towards Risk', Research in Economic History 1 (Fall 1976): 124-70.

McCloskey, Donald, 'The Prudent Peasant: New Findings on Open Fields', Journal of Economic History 51 (1991), 343-355.

Melton, Edgar, 'Enlightened Seigniorialism and Its Dilemmas in Serf Russia, 1750-1830', Journal of Modern History, 62 (1990), 675-708.

Nafziger, Steven, 'Land Redistributions and the Russian Peasant Commune in the LateImperial Period', mimeo (Department of Economics, Yale University, 2005) [URL http://www.econ.yale.edu/seminars/echist/eh04-05/nafziger120104.pdf].

North, Douglass C., 'Institutional Change and Economic Growth', Journal of Economic History, 31 (1971), 118-125.

North, Douglass C., Structure and Change in Economic History (New York / London, 1981).

North, Douglass C., Institutions, Institutional Change, and Economic Performance (Cambridge, 1990).

North, Douglass C., Summerhill, William, and Weingast, Barry R., 'Order, Disorder, and Economic Change: Latin America vs. North America', in Bruce Bueno de Mesquita and Hilton Root (eds.), Governing for Prosperity. (New Haven, 2000).

North, Douglass C., and Thomas, Robert Paul, 'An Economic Theory of the Growth of the Western World', Economic History Review, NS 23 (1970), 1-17.

North, Douglass C., and Thomas, Robert Paul, 'The Rise and Fall of the Manorial System: A Theoretical Model', Journal of Economic History, 31 (1971), 777-803.

North, Douglass C., and Thomas, Robert Paul, The Rise of the Western World: A New Economic History (Cambridge / New York, 1973).

Nugent, Jeffrey B. and Sanchez, Nicolas, 'The Efficiency of the Spanish Mesta Reconsidered: a Parable', Explorations in Economic History, 26 (1989), 261-284.

Ogilvie, Sheilagh, State Corporatism and Proto-Industry: the Württemberg Black Forest, 1580-1797 (Cambridge, 1997).

Ogilvie, Sheilagh, 'The German State: a Non-Prussian View', in E. Hellmuth \& J. Brewer (eds.), Rethinking Leviathan: The Eighteenth-Century State in Britain and Germany (Oxford, 1999), 167-202. 
Ogilvie, Sheilagh, 'The Economic World of the Bohemian Serf: Economic Concepts, Preferences and Constraints on the Estate of Friedland, 1583-1692', Economic History Review, 54 (2001), 430-453.

Ogilvie, Sheilagh, A Bitter Living: Women, Markets, and Social Capital in Early Modern Germany (Oxford, 2003).

Ogilvie, Sheilagh, 'Guilds, Efficiency and Social Capital: Evidence from German ProtoIndustry', Economic History Review, 57 (2004), 286-333.

Ogilvie, Sheilagh, 'Women and Labour Markets in Early Modern Germany', Jahrbuch für Wirtschaftsgeschichte / Economic History Yearbook, 2004:2 (2004), 25-60.

Ogilvie, Sheilagh, 'Communities and the "Second Serfdom" in Early Modern Bohemia', $\underline{\text { Past }}$ and Present, 187 (2005), 69-119.

Ogilvie, Sheilagh, 'The Use and Abuse of Trust: Social Capital and its Deployment by Early Modern Guilds', Jahrbuch für Wirtschaftsgeschichte / Economic History Yearbook, 2005:1 (2005), 15-52.

Ogilvie, Sheilagh, “"Eine sauere Nahrung”. Frauen, Märkte, und soziales Kapital im frühmodernen Deutschland', Jahrbuch für Regionalgeschichte, 24 (2006), 13-36.

Ogilvie, Sheilagh, 'Can We Rehabilitate the Guilds? A Sceptical Re-Appraisal', Cambridge Working Papers in Economics (2007).

Ogilvie, Sheilagh, 'Rehabilitating the Guilds: a Response', Economic History Review, 61 (2008).

Ogilvie, Sheilagh, and Edwards, Jeremy, 'Women and the Second Serfdom: Evidence from Early Modern Bohemia', Journal of Economic History, 60 (2000), 961-994.

Pazderova, Alena, 'Gutsherrschaft und Untertanen in der Herrschaft Reichenau an der Kněžna. Zur "zweiten Leibeigenschaft” in Böhmen im 18. Jahrhundert', in Markus Cerman and Robert Luft (eds.), Untertanen, Herrschaft und Staat in Böhmen und im 'Alten Reich'. Sozialgeschichtliche Perspektiven (Munich, 2005), 177-202.

Persson, Karl Gunnar, Pre-industrial Economic Growth: Social Organization and Technological Progress in Europe (Oxford, 1988).

Peters, Jan (ed.), Gutsherrschaft als soziales Modell. Vergleichende Betrachtungen zu Funktionsweise frühneuzeitlicher Agrargesellschaften (Munich, 1995).

Peters, Jan (ed.), Gutsherrschaftsgesellschaften im europäischen Vergleich (Berlin, 1997).

Pfister, Ulrich, 'Craft Guilds and Proto-Industrialization in Europe, 16th to 18th Centuries', in S. R. Epstein, H. G. Haupt, Carlo Poni, and Hugo Soly (eds.), Guilds, Economy and Society (Sevilla, 1998), 11-24.

Pomeranz, Kenneth, The Great Divergence: China, Europe, and the Making of the Modern World Economy (Princeton, 2000).

Pope, Alexander, 'Essay on Man' (1732).

Reith, R., 'Arbeitsmigration und Technologietransfer in der Habsburgmonarchie in der zweiten Hälfte des 18. Jahrhunderts - Die Gesellenwanderung aus der Sicht der Kommerzienkonzesse', Blätter für Technikgeschichte, 56 (1994), 9-33.

Richardson, Gary S., 'Brand Names before the Industrial Revolution', University of California Irvine School of Social Sciences Working Papers (2004).

Richardson, Gary, 'Guilds, Laws, and Markets for Manufactured Merchandise in LateMedieval England', Explorations in Economic History, 41 (2004), 1-25.

Richardson, Gary, 'The Prudent Village: Risk Pooling Institutions in Medieval English Agriculture', Journal of Economic History, 65 (2005), 386-413.

Robisheaux, Thomas, Rural Society and the Search for Order in Early Modern Germany (Cambridge, 1989).

Rodrik, Dani, Subramanian, Arvind, and Trebbi, Francesco, 'Institutions Rule: the Primacy of Institutions Over Geography and Integration in Economic Development', CEPR Discussion Papers 3643 (2002).

Sachs, Jeffrey D., 'Tropical Underdevelopment', NBER Working Paper 8119 (2001).

Schneider, Friedrich, 'Shadow Economies and Corruption All Over the World: What Do We Really Know?”, IZA Discussion Paper 2315 (2006). 
Scott, Peter, 'Path Dependence and Britain's "Coal Wagon Problem”, Explorations in Economic History, 38, 3 (2001), 366-385.

Stabel, Peter, 'Guilds in Late Medieval Flanders: Myths and Realities of Guild Life in an Export-Oriented Environment', Journal of Medieval History, 30 (2004), 187-212.

Stigler, George J. and Becker, Gary S., 'De Gustibus Non Est Disputandum', American Economic Review, 67, 2 (1977), pp. 76-90.

Stefanová, Dana, 'Erbschaftspraxis und Handlungsspielräume der Untertanen in einer gutsherrschaftlichen Gesellschaft. Die Herrschaft Frýdlant in Nordböhmen, 15581750.' (Ph.D. dissertation, University of Vienna, 1999).

Townsend, Robert M., The Medieval Village Economy: a Study of the Pareto Mapping in General Equilibrium Models (Princeton, NJ, 1993).

Troeltsch, Walter, Die Calwer Zeughandlungskompagnie und ihre Arbeiter (Jena, 1897).

Van den Heuvel, Danielle, 'Female Traders in the Dutch Republic. Retailers in EighteenthCentury 's-Hertogenbosch: a Case Study', paper presented at the Quantitative Economic History Seminar, Cambridge, January 2006.

Van Zanden, Jan Luiten, 'Common Workmen, Philosophers and the Birth of the European Knowledge Economy: about the Price and the Production of Useful Knowledge in Europe 1350-1800', paper presented at the GEHN Conference on Useful Knowledge, Leiden, September 2004; revised 12 October 2004, [http://www.iisg.nl/research/jvzknowledge_economy.pdf].

Véliz, Claudio, The New World of the Gothic Fox: Culture and Economy in English and Spanish America (Princeton, 1993).

Volckart, Oliver, 'The Economics of Feuding in Late Medieval Germany', Explorations in Economic History 41 (2004) 282-299.

Volckart, Oliver and Mangels, Antje, 'Are the Roots of the Modern Lex Mercatoria Really Medieval?', Southern Economic Journal, 65, 3 (1999), pp. 427-450.

Weber, Max, The Protestant Ethic and the Spirit of Capitalism (London, 1930).

Williamson, Oliver E., 'Transaction Cost Economics: How it Works; Where it is Headed', De Economist 146:1 (1998), 23-58.

Wittman, Donald, 'Why Democracies Produce Efficient Results', Journal of Political Economy, 97 (1989), 1395-1424. 


\section{CESifo Working Paper Series}

for full list see www.cesifo-group.org/wp

(address: Poschingerstr. 5, 81679 Munich, Germany, office@cesifo.de)

2004 Harrie A. A. Verbon, Migrating Football Players, Transfer Fees and Migration Controls, May 2007

2005 Helmuth Cremer, Jean-Marie Lozachmeur and Pierre Pestieau, Income Taxation of Couples and the Tax Unit Choice, May 2007

2006 Michele Moretto and Paolo M. Panteghini, Preemption, Start-Up Decisions and the Firms’ Capital Structure, May 2007

2007 Andreas Schäfer and Thomas M. Steger, Macroeconomic Consequences of Distributional Conflicts, May 2007

2008 Mikael Priks, Judiciaries in Corrupt Societies, June 2007

2009 Steinar Holden and Fredrik Wulfsberg, Downward Nominal Wage Rigidity in the OECD, June 2007

2010 Emmanuel Dhyne, Catherine Fuss, Hashem Pesaran and Patrick Sevestre, Lumpy Price Adjustments: A Microeconometric Analysis, June 2007

2011 Paul Belleflamme and Eric Toulemonde, Negative Intra-Group Externalities in TwoSided Markets, June 2007

2012 Carlos Alós-Ferrer, Georg Kirchsteiger and Markus Walzl, On the Evolution of Market Institutions: The Platform Design Paradox, June 2007

2013 Axel Dreher and Martin Gassebner, Greasing the Wheels of Entrepreneurship? The Impact of Regulations and Corruption on Firm Entry, June 2007

2014 Dominique Demougin and Claude Fluet, Rules of Proof, Courts, and Incentives, June 2007

2015 Stefan Lachenmaier and Horst Rottmann, Effects of Innovation on Employment: A Dynamic Panel Analysis, June 2007

2016 Torsten Persson and Guido Tabellini, The Growth Effect of Democracy: Is it Heterogenous and how can it be Estimated?, June 2007

2017 Lorenz Blume, Jens Müller, Stefan Voigt and Carsten Wolf, The Economic Effects of Constitutions: Replicating - and Extending - Persson and Tabellini, June 2007

2018 Hartmut Egger and Gabriel Felbermayr, Endogenous Skill Formation and the Source Country Effects of International Labor Market Integration, June 2007

2019 Bruno Frey, Overprotected Politicians, June 2007 
2020 Jan Thomas Martini, Rainer Niemann and Dirk Simons, Transfer Pricing or Formula Apportionment? Tax-Induced Distortions of Multinationals' Investment and Production Decisions, June 2007

2021 Andreas Bühn, Alexander Karmann and Friedrich Schneider, Size and Development of the Shadow Economy and of Do-it-yourself Activities in Germany, June 2007

2022 Michael Rauscher and Edward B. Barbier, Biodiversity and Geography, June 2007

2023 Gunther Schnabl, Exchange Rate Volatility and Growth in Emerging Europe and East Asia, June 2007

2024 Erkki Koskela and Ronnie Schöb, Tax Progression under Collective Wage Bargaining and Individual Effort Determination, June 2007

2025 Jay Pil Choi and Marcel Thum, The Economics of Politically Connected Firms, June 2007

2026 Jukka Pirttilä and Roope Uusitalo, Leaky Bucket in the Real World: Estimating Inequality Aversion Using Survey Data, June 2007

2027 Ruslan Lukach, Peter M. Kort and Joseph Plasmans, Strategic R\&D with Knowledge Spillovers and Endogenous Time to Complete, June 2007

2028 Jarko Fidrmuc, Neil Foster and Johann Scharler, Labour Market Rigidities, Financial Integration and International Risk Sharing in the OECD, June 2007

2029 Bernardina Algieri and Thierry Bracke, Patterns of Current Account Adjustment Insights from Past Experience, June 2007

2030 Robert Dur and Hein Roelfsema, Social Exchange and Common Agency in Organizations, June 2007

2031 Alexander Libman and Lars P. Feld, Strategic Tax Collection and Fiscal Decentralisation: The Case of Russia, June 2007

2032 Øystein Foros, Hans Jarle Kind and Greg Shaffer, Resale Price Maintenance and Restrictions on Dominant Firm and Industry-Wide Adoption, June 2007

2033 Jan K. Brueckner and Kurt Van Dender, Atomistic Congestion Tolls at Concentrated Airports? Seeking a Unified View in the Internalization Debate, June 2007

2034 Viet Do and Ngo Van Long, International Outsourcing under Monopolistic Competition: Winners and Losers, June 2007

2035 Nadia Fiorino and Roberto Ricciuti, Determinants of Direct Democracy, June 2007

2036 Burkhard Heer and Alfred Maussner, Inflation and Output Dynamics in a Model with Labor Market Search and Capital Accumulation, June 2007 
2037 Konstantinos Angelopoulos, Jim Malley and Apostolis Philippopoulos, Public Education Expenditure, Growth and Welfare, June 2007

2038 Maarten Bosker, Steven Brakman, Harry Garretsen and Marc Schramm, Adding Geography to the New Economic Geography, June 2007

2039 Steffen Henzel, Oliver Hülsewig, Eric Mayer and Timo Wollmershäuser, The Price Puzzle Revisited: Can the Cost Channel Explain a Rise in Inflation after a Monetary Policy Shock?, July 2007

2040 Rosario Crinò, Service Offshoring and White-Collar Employment, July 2007

2041 Carsten Hefeker and Michael Neugart, Labor Market Regulation and the Legal System, July 2007

2042 Bart Cockx and Muriel Dejemeppe, Is the Notification of Monitoring a Threat to the Unemployed? A Regression Discontinuity Approach, July 2007

2043 Alfons J. Weichenrieder, Profit Shifting in the EU: Evidence from Germany, July 2007

2044 Annika Alexius and Bertil Holmlund, Monetary Policy and Swedish Unemployment Fluctuations, July 2007

2045 Axel Dreher, Jan-Egbert Sturm and Jakob de Haan, Does High Inflation Cause Central Bankers to Lose their Job? Evidence Based on a New Data Set, July 2007

2046 Guglielmo Maria Caporale and Luis A. Gil-Alana, Long Run and Cyclical Dynamics in the US Stock Market, July 2007

2047 Alessandro Balestrino, It is a Theft but not a Crime, July 2007

2048 Daniel Becker and Michael Rauscher, Fiscal Competition in Space and Time: An Endogenous-Growth Approach, July 2007

2049 Yannis M. Ioannides, Henry G. Overman, Esteban Rossi-Hansberg and Kurt Schmidheiny, The Effect of Information and Communication Technologies on Urban Structure, July 2007

2050 Hans-Werner Sinn, Please bring me the New York Times - On the European Roots of Richard Abel Musgrave, July 2007

2051 Gunther Schnabl and Christian Danne, A Role Model for China? Exchange Rate Flexibility and Monetary Policy in Japan, July 2007

2052 Joseph Plasmans, Jorge Fornero and Tomasz Michalak, A Microfounded Sectoral Model for Open Economies, July 2007

2053 Vesa Kanniainen and Panu Poutvaara, Imperfect Transmission of Tacit Knowledge and other Barriers to Entrepreneurship, July 2007 
2054 Marko Koethenbuerger, Federal Tax-Transfer Policy and Intergovernmental PreCommitment, July 2007

2055 Hendrik Jürges and Kerstin Schneider, What Can Go Wrong Will Go Wrong: Birthday Effects and Early Tracking in the German School System, July 2007

2056 Bahram Pesaran and M. Hashem Pesaran, Modelling Volatilities and Conditional Correlations in Futures Markets with a Multivariate t Distribution, July 2007

2057 Walter H. Fisher and Christian Keuschnigg, Pension Reform and Labor Market Incentives, July 2007

2058 Martin Altemeyer-Bartscher, Dirk T. G. Rübbelke and Eytan Sheshinski, Policies to Internalize Reciprocal International Spillovers, July 2007

2059 Kurt R. Brekke, Astrid L. Grasdal and Tor Helge Holmås, Regulation and Pricing of Pharmaceuticals: Reference Pricing or Price Cap Regulation?, July 2007

2060 Tigran Poghosyan and Jakob de Haan, Interest Rate Linkages in EMU Countries: A Rolling Threshold Vector Error-Correction Approach, July 2007

2061 Robert Dur and Klaas Staal, Local Public Good Provision, Municipal Consolidation, and National Transfers, July 2007

2062 Helge Berger and Anika Holler, What Determines Fiscal Policy? Evidence from German States, July 2007

2063 Ernesto Reuben and Arno Riedl, Public Goods Provision and Sanctioning in Privileged Groups, July 2007

2064 Jan Hanousek, Dana Hajkova and Randall K. Filer, A Rise by Any Other Name? Sensitivity of Growth Regressions to Data Source, July 2007

2065 Yin-Wong Cheung and Xing Wang Qian, Hoarding of International Reserves: Mrs Machlup's Wardrobe and the Joneses, July 2007

2066 Sheilagh Ogilvie, 'Whatever Is, Is Right'?, Economic Institutions in Pre-Industrial Europe (Tawney Lecture 2006), August 2007 